\title{
Data report: Pliocene and Pleistocene diatom floras and taxonomic notes from the Canterbury Basin (IODP Expedition 317 Hole U1352B), off New Zealand ${ }^{1}$
}

\author{
Itsuki Suto, ${ }^{2}$ Keita Kawamura, ${ }^{3}$ and Shun Chiyonobu ${ }^{4}$
}

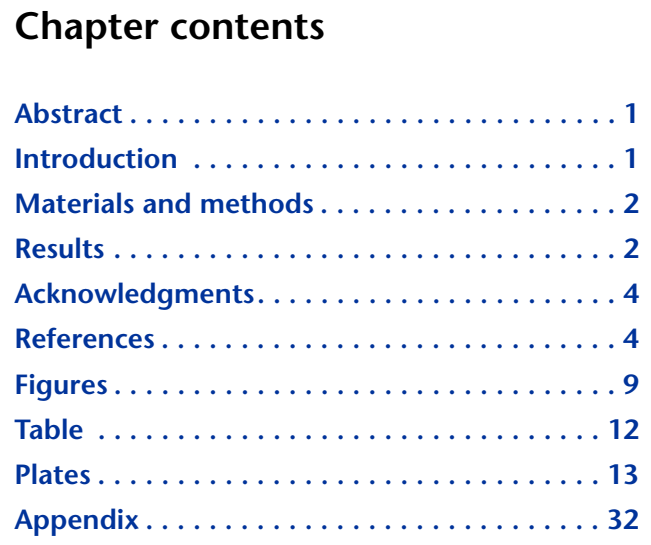

1'Suto, I., Kawamura, K., and Chiyonobu, S., 2013. Pliocene and Pleistocene diatom floras and taxonomic notes from the Canterbury Basin (IODP Expedition 317 Hole U1352B), off New Zealand. In Fulthorpe, C.S., Hoyanagi, K., Blum, P., and the Expedition 317 Scientists, Proc. IODP, 317: Tokyo (Integrated Ocean Drilling Program Management International, Inc.). doi:10.2204/ iodp.proc.317.202.2013

${ }^{2}$ Department of Earth and Planetary Sciences, Graduate School of Environmental Studies, Nagoya University, Furo-cho, Chikusa, Nagoya, Aichi 464-8601, Japan. suto.itsuki@a.mbox.nagoya-u.ac.jp ${ }^{3}$ Nissei Gakuen, 2739 Hattaino, Hakusan-cho, Tsu, Mie 515-2692, Japan.

${ }^{4}$ Research Institute of Innovative Technology for the Earth, $\mathrm{CO}_{2}$ Storage Research Group, 9-2 Kizugawadai, Kizugawa, Kyoto 619-0292, Japan.

\section{Abstract}

Diatom analyses of upper Pliocene and Pleistocene sediments ( 2780-290 ka age, dated according to the results of onboard calcareous nannoplankton biostratigraphic research) from the Canterbury Basin continental slope (Hole U1352B of Integrated Ocean Drilling Program Expedition 317) reveal strong warm and cold fluctuations that coincide with global benthic foraminiferal $\delta^{18} \mathrm{O}$ records, although the preservation and occurrences of diatoms were generally poor and rare, respectively, and the diatom biostratigraphic events were unknown. Moreover, abundant occurrences of diatom resting spores from 1700 to 1100 ka indicate that eutrophication increased along the coastal region after upwelling strengthened and the nutrient supply was unstable and sporadic from 1250 to $1100 \mathrm{ka}$.

\section{Introduction}

Integrated Ocean Drilling Program (IODP) Expedition 317 cored subtidal to lower bathyal sediments of Holocene to late Eocene age (0-36 Ma) in a transect across the Canterbury Basin continental shelf and slope (Fig. F1). Sequence stratigraphic processes influenced calcareous nannofossil and planktonic foraminiferal assemblages, and these are strongly reflected in the overall abundance, preservation, and assemblage variations in relation to lithology. These variations may have been influenced by a number of factors, including global climate, local paleoceanography, changes in sea level, and tectonic uplift along the Alpine Fault.

Quaternary diatom assemblages of the southwestern midlatitude Pacific Ocean are not well known because of their poor preservation in predominantly calcareous sediments, although several expeditions (e.g., Deep Sea Drilling Project [DSDP] Legs 29 and 90 and Ocean Drilling Program [ODP] Leg 181) have investigated Cretaceous through Neogene sediments in the region (Hajós and Stradner, 1975; Hajós, 1976; Ciesielski, 1986; McMinn et al., 2001). Moreover, diatom assemblages from the shallower marine environments, including nonmarine and littoral facies in the southwestern Pacific Ocean, are less well known. This report presents the diatom occurrences and abundances and range charts for the taxa recovered in cores from Hole U1352B. 


\section{Materials and methods}

During Expedition 317, we drilled three shelf sites (U1351, U1353, and U1354) and one slope site (U1352) along a transect perpendicular to the margin of the Canterbury Basin (Fig. F1). For age control, all core catcher samples were analyzed aboard ship for calcareous nannofossil, planktonic and benthic foraminifer, and diatom biostratigraphy in Holocene to Eocene sediments (see the "Expedition 317 summary" chapter [Expedition 317 Scientists, 2011a]). Continental slope Site U1352 represents a complete section of modern slope terrigenous sediment, mainly in Holes U1352A and U1352B, to hard Eocene limestone sediments at the bottom of Hole U1352C, with all the associated lithological, biostratigraphical, physical, geochemical, and microbiological transitions.

Hole U1352B was the deepest water site drilled during the expedition. Shipboard study revealed few diatoms, but onshore diatom investigation recognized moderately continuous occurrences of fossil diatom assemblages in upper Pliocene to Pleistocene sediments with better preservation than that seen in samples from the shelf sites. Our postcruise diatom analysis, therefore, focused on 437 samples from Hole U1352B. Silt to clay samples were selected from every core section (yielding a sample interval of approximately every $1.5 \mathrm{~m}$ ).

Counting and other procedures followed those of Akiba (1986), with a minor modification:

1. About $1.0 \mathrm{~g}$ of each sample was oven-dried for 2 $\mathrm{h}$ at $100^{\circ} \mathrm{C}$, mixed with $\sim 30 \mathrm{~mL}$ of hydrogen peroxide $\left(\mathrm{H}_{2} \mathrm{O}_{2}, 10 \%-15 \%\right)$, and boiled in a $200 \mathrm{~mL}$ beaker to decompose sediment aggregates and oxidize organic matter.

2. After cooling, $\sim 30 \mathrm{~mL}$ of hydrochloric acid $(\mathrm{HCl}$, $30 \%)$ was added and boiled to dissolve calcareous material (including calcareous nannofossils and foraminifers) to concentrate the siliceous fossil material.

3. After boiling for $\sim 5 \mathrm{~min}$, the beaker was filled with distilled water and allowed to stand for $8 \mathrm{~h}$.

4. After standing, the residue was separated by decanting the acid water, and the beaker was refilled with distilled water. This process was repeated five times.

5. In order to remove clay fractions, a flocculating solution $\left(\mathrm{Na}_{4} \mathrm{P}_{2} \mathrm{O}_{7}, 0.01 \mathrm{~N}\right)$ was added to the beaker and allowed to stand for $8 \mathrm{~h}$. The residue was separated by decanting the water. The beaker was filled again with sodium phosphate solution, and this process was repeated until the supernatant liquid became clear. The remaining residue contained diatoms, other siliceous fos- sils (e.g., silicoflagellates and radiolarians), and coarse unbroken mudstone fragments. The residues were preserved in $5 \mathrm{~mL}$ bottles with distilled water.

Diatom abundance is expressed as an approximate number of diatom valves per slide $(18 \mathrm{~mm} \times 18 \mathrm{~mm}$ coverslip) calculated using the length of scan lines needed to count at least 100 diatom valves. In the case where there were fewer than 100 valves, counts were stopped after covering $\sim 320 \mathrm{~mm}^{2}$ (i.e., whole coverslip observation). Resting spores of the shallowmarine diatom genus Chaetoceros, which have generally been neglected in diatom analyses although they indicate coastal upwelling and a high-nutrient environment, were counted separately. Diatom and spore occurrences and the presence (indicated by a "+" in Table T1) of silicoflagellates, radiolarians, and pollen in Hole U1352B recognized until at least 100 diatom valves were enumerated in separate scan line(s) or until $\sim 320 \mathrm{~mm}^{2}$ of the coverslip was scanned. The results are given in Table T1.

For diatom biostratigraphic assignments, ages of bioevents that define or characterize certain horizons are based mainly on the diatom biochronology for the Antarctic Neogene of Cody et al. (2008).

Light microscope observations and the photomicroscopy of diatoms and other microfossils (i.e., silicoflagellates, radiolarians, and pollen) were carried out using an Olympus BX40 light microscope with a differential interference contrast condenser at magnifications of $200 \times$ for scanning and $400 \times$ and $600 \times$ for identification and photography using a digital camera system (Olympus DP20). Scanning electron microscopy was performed using a Hitachi High-Technology SEM SU6600 at several magnifications in the Laboratory of Geobiology at Nagoya University (Japan).

\section{Results}

Detailed diatom assemblage data are given by species and sample number in Figure F2 and Table T1. These revealed a low to high diversity, although abundances in the majority of samples containing diatoms were low with moderate to poor preservation. Several robust diatom species with thickly silicified valves (e.g., Paralia sulcata, Thalassionema nitzschioides, and Chaetoceros resting spores) were better preserved than delicate forms with weakly silicified valves. The number of diatom valves preserved in sediments depends on diatom productivity, preservation, and/or dissolution of the valves and dilution with terrigenous and/or organic materials (Koizumi et al., 2004). Although the reasons for low diatom occurrences in cores from Hole U1352B are not clear, 
poor preservation might result from dissolution by pore water in coarse-grained sediments (see the "Site U1352" chapter [Expedition 317 Scientists, 2011c]).

Although the diatom occurrences are not continuous and their abundances are generally few, some slides contain common (1-10 valves/field of view [FOV]) to few ( $\geq 1$ valve/10 FOV and $<1$ valve/FOV) abundances. Therefore, 111 slides with better preserved and more abundant diatoms ( $\geq 50$ valves, highlighted in Table T1) were selected to provide paleoceanographical data (Fig. F3). After procedures to concentrate siliceous microfossils, materials including diatoms, poorly preserved silicoflagellates, radiolarians, and several types of pollen with very low abundances were also recognized in some slides (indicated by a "+" in Table T1).

In general, Expedition 317 age assignments relied on nannofossils for the Holocene to middle Pliocene and planktonic foraminifers for the early Pliocene to late Miocene. Both fossil groups were integral to biostratigraphic control for the middle Miocene (Fig. F2). Cody et al. (2008) achieved a remarkable advance in Neogene diatom biostratigraphy of the Antarctic by integrating diatom biostratigraphy, magnetostratigraphy, and tephrostratigraphy from 32 Neogene sections around the Southern Ocean and the Antarctic continental margin. The locations are concentrated around the Atlantic sector of the Southern Ocean except for those from the Dry Valley Drilling Project (DVDP), Cenozoic investigations in the western Ross Sea (CIROS), and DSDP Leg 28. Nevertheless, we have tried to use their model in order to see whether it can be applied in the case of Expedition 317 sites influenced by the Subantarctic Front in the Pacific sector.

In this study, we mainly used the age model provided by the shipboard calcareous nannoplankton biostratigraphy (see the "Methods" chapter [Expedition 317 Scientists, 2011b]) because most occurrences of diatom markers are sporadic except for some discussed below. Compared to the nannofossil datums, the ages of the first appearance of Fragilariopsis rhombica in Sample 317-U1352B-59X-1W, 99$100 \mathrm{~cm}$ (505.29 mbsf) (Total Range Model [TRM] = 1.69-1.92 Ma; Average Range Model [ARM] = 1.37$1.45 \mathrm{Ma}$ in Cody et al., 2008), and the last appearance of Hemidiscus karstenii in Sample 317-U1352B$12 \mathrm{H}-4 \mathrm{~W}, 130-131 \mathrm{~cm}$ (108.96 mbsf) (TRM = 0.28$0.33 \mathrm{Ma}$; ARM = 0.35-0.43 Ma), are consistent. Several first and last occurrences (FOs and LOs, respectively) of other biostratigraphic diatom markers indicated by Cody et al. (2008) were also recognized in this study (Fig. F2), but these taxa appeared sporadically above/below these levels and their reliability is uncertain.
Biostratigraphically useful diatom resting spores have been found in several studies (e.g., Suto, 2006b, 2006c, 2007). The LO of Liradiscus var. castaneus recognized in Sample 317-U1352B-25H-3W, 25-26 cm (220.95 mbsf), from the middle Pleistocene ( 0.5 Ma) corresponds to that reported from the middle Pleistocene Zone NPD 11 of Yanagisawa and Akiba (1998) at DSDP Site 436, northwestern Pacific. Therefore, this species might be a potentially useful marker for improving the resolution of diatom biostratigraphy in the North and South Pacific Oceans.

Diatom assemblages from Hole U1352B contain several ecotype diatoms that typically live in oceanic (60 species), littoral to neritic (32 species), and freshwater (7 genus-level taxa) environments, including some warm- and cold-water species (Fig. F3). Moreover, 23 fossil resting spore morphospecies of the marine genus Chaetoceros, which is indicative of high productivity in nearshore upwelling regions and coastal areas, are also preserved (Fig. F2).

Oceanic diatoms live in the open ocean, away from coastal influences, and are transported by wind and currents. Neritic to littoral diatoms in shallower waters are also affected by coastal processes and reduced salinity resulting from freshwater drainage from land. The oscillations of these floras are somewhat heterogeneous. The large fluctuations of oceanic and neritic to littoral species indicate that there were several transgressions and regressions at the site (Fig. F3). Of those, stronger regressions at $\sim 1600$, 1140 , and $600 \mathrm{ka}$ coincide with slight peaks in landderived freshwater diatoms at these ages (Fig. F3), although freshwater diatoms do not commonly coincide with continental detritus throughout the core. These signals of regression, however, generally coincide with the results from planktonic foraminiferal abundances (see the "Site U1352" chapter [Expedition 317 Scientists, 2010c]). On the other hand, freshwater diatoms also peak along with increases of oceanic species that indicate transgressions at $~ 1300$, 800, and $350 \mathrm{ka}$ (Fig. F3).

During warm periods indicated by abundant occurrences of warm-water species, oceanic species are also abundant. This synchronous fluctuation indicates transgressions took place during warm periods. On the other hand, some peaks in cold-water species are simultaneous with those of warm-water taxa. For the most part, warm-water species increase during the warm marine isotope stages (MIS) of Lisiecki and Raymo (2005; i.e., MIS 39, 37, 35, 17, 11, and 9), but a peak in warm-water species is present during the cold period MIS 56 (Fig. F3).

The marine diatom genus Chaetoceros is a major contributor to primary production in nearshore upwelling regions and coastal areas (Rines and Hargraves, 
1988), and its resting spores are usually taken as a measure of diatom productivity and an indicator of nutrient-rich conditions (Sancetta, 1982). Therefore, abundant occurrences of resting spores from 1700 to $1100 \mathrm{ka}$ indicate that eutrophication increased in the coastal regions after upwelling strengthened. Furthermore, resting spores are believed to increase because of an unstable and sporadic supply of nutrients from upwelling rather than seasonal upwelling conditions (Suto, 2006b). Abrupt increases of resting spores, therefore, from 1250 to $1100 \mathrm{ka}$, during the transitional period from 41,000 to 100,000 k.y. MIS cycles, indicate that the upwelling system became unstable. In the future, we will reconstruct the past environments of marine deposition under the influence of coastal upwelling and river input by comparing the results in this paper to other paleoenvironmental analyses.

\section{Acknowledgments}

We express many thanks to all Expedition 317 scientists, especially Co-Chief Scientists Craig S. Fulthorpe and Koichi Hoyanagi, and the crew of the JOIDES Resolution for their participation. We also acknowledge reviewer Dr. Sherwood W. Wise Jr. and editor Lorri Peters for their invaluable comments to this manuscript. Extended thanks go to Professor David M. Harwood (University of Nebraska-Lincoln) for providing valuable discussion on the Antarctic diatom taxonomy and his kind revision for our manuscript. Our thanks are also extended to our colleagues of the Laboratory of Geobiology, Nagoya University, and especially Prof. Yasufumi Iryu (Tohoku University) for their help and advice. We also thank to Drs. Kota Katsuki (Korea Institute of Geoscience and Mineral Resources, KIGAM) and Jonaotaro Onodera (JSPS Res. Fellowship, JAMSTEC) for their helpful discussion about taxonomic study. This research used samples and data provided by the Integrated Ocean Drilling Program (IODP). Funding for this research was provided by Grant-in-Aid from the Ministry of Education, Science and Culture of Japan (20740299 awarded to Itsuki Suto for 2008-2010 and 23340154 to Koichi Hoyanagi for 2011-2013).

\section{References}

Akiba, F., 1986. Middle Miocene to Quaternary diatom biostratigraphy in the Nankai Trough and Japan Trench, and modified lower Miocene through Quaternary diatom zones for middle-to-high latitudes of the north Pacific. In Kagami, H., Karig, D.E., Coulbourn, W.T., et al., Init. Repts. DSDP, 87: Washington, DC (U.S. Govt. Printing Office), 393-481. doi:10.2973/

dsdp.proc.87.106.1986
Armand, L.K., and Zielinski, U., 2001. Diatom species of the genus Rhizosolenia from Southern Ocean sediments: distribution and taxonomic notes. Diatom Res., 16(2):259-294. doi:10.1080/0269249X.2001.9705520

Arney, J.E., McGonigal, K.L., Ladner, B.C., and Wise, S.W., Jr., 2003. Lower Oligocene to middle Miocene diatom biostratigraphy of ODP Site 1140, Kerguelen Plateau. In Frey, F.A., Coffin, M.F., Wallace, P.J., and Quilty, P.G. (Eds.), Proc. ODP, Sci. Results, 183: College Station, TX (Ocean Drilling Program), 1-21. doi:10.2973/ odp.proc.sr.183.009.2003

Bailey, J.W., 1856. Notice of microscopic forms found in the soundings of the Sea of Kamtschatka. Am. J. Sci. Arts, 22(64):1-6.

Baldauf, J.G., and Barron, J.A., 1991. Diatom biostratigraphy: Kerguelen Plateau and Prydz Bay regions of the Southern Ocean. In Barron, J., Larsen, B., et al., Proc. ODP, Sci. Results, 119: College Station, TX (Ocean Drilling Program), 547-598. doi:10.2973/ odp.proc.sr.119.135.1991

Barron, J.A., 1985. Miocene to Holocene planktic diatoms. In Bolli, H.M., Saunders, J.B., and Perch-Nielsen, K. (Eds.), Plankton Stratigraphy: Cambridge (Cambridge Univ. Press), 763-809.

Barron, J.A., 1996. Diatom constraints on the position of the Antarctic Polar Front in the middle part of the Pliocene. Mar. Micropaleontol., 27(1-4):195-213. doi:10.1016/0377-8398(95)00060-7

Bohaty, S.M., Wise, S.W., Jr., Duncan, R.A., Moore, C.L., and Wallace, P.J., 2003. Neogene diatom biostratigraphy, tephra stratigraphy, and chronology of ODP Hole 1138A, Kerguelen Plateau. In Frey, F.A., Coffin, M.F., Wallace, P.J., and Quilty, P.G. (Eds.), Proc. ODP, Sci. Results, 183: College Station, TX (Ocean Drilling Program), 1-53. doi:10.2973/odp.proc.sr.183.016.2003

Brightwell, T., 1858. Remarks on the genus "Rhizosolenia" of Ehrenberg. Q. J. Microsc. Sci., 6(1):93-95. doi:10.1111/j.1365-2818.1858.tb04544.X

Brown, N.E., 1920. Some new and old Antarctic diatoms. Engl. Mechanic., 111(2881):210-233.

Brun, J., 1894. Espéce nouvelles. Diatomiste, 2(17):86-88.

Burckle, L.H., 1972. Late Cenozoic planktonic diatom zones from the eastern equatorial Pacific. In Simonsen, R. (Ed.), First Symposium on Recent and Fossil Marine Diatoms. Nova Hedwegia Beih., 39:217-246.

Castracane, C.A.F., 1886a. Report of the Scientific Results of the Voyage of H.M.S. Challenger during the Years 1873-1876. Botany, 2.

Castracane, F., 1886b. Catalogo delle Diatomee rinvenute da D. Pantanelli nel calcare biancastro friable sovrapposto al bacino di lignite di Spoleto. Proc. Soc. Nat. Sci. Pisa Tuscany, 1886.

Censarek, B., and Gersonde, R., 2002. Miocene diatom biostratigraphy at ODP Sites 689, 690, 1088, 1092 (Atlantic sector of the Southern Ocean). Mar. Micropaleontol., 45(3-4):309-356. doi:10.1016/S0377-8398(02)00034-8

Ciesielski, P.F., 1983. The Neogene and Quaternary diatom biostratigraphy of subantarctic sediments, Deep Sea Drilling Project Leg 71. In Ludwig, W.J., Krasheninnikov, V.A., et al., Init. Repts. DSDP, 71: Washington, DC 
(U.S. Govt. Printing Office), 635-666. doi:10.2973/ dsdp.proc.71.125.1983

Ciesielski, P.F., 1986. Middle Miocene to Quaternary diatom biostratigraphy of Deep Sea Drilling Project Site 594, Chatham Rise, southwest Pacific. In Kennett. J.P., von der Borch, C.C., et al., Init. Repts. DSDP, 90: Washington, DC (U.S. Govt. Printing Office), 863-885. doi:10.2973/dsdp.proc.90.115.1986

Cleve, P.T., 1873. On diatoms from the Arctic Sea. K. Sven. Vetenskapsakad. Handl., Bihang, 1(13).

Cleve, P.T., 1881. On some new and little known diatoms. K. Sven. Vetenskapsakad. Handl., Bihang, 18(5).

Cleve, P.T., 1894. Synopsis of the naviculoid diatoms, Part I. K. Sven. Vetenskapsakad. Handl., Bihang, 26(2).

Cleve, P.T., 1896. Diatoms from Baffin Bay and Davis Strait. K. Sven. Vetenskapsakad. Handl., Bihang, 22(4).

Cleve, P.T., 1900. Plankton from the southern Atlantic and the southern Indian Ocean. Öfvers. K.. Vetenskapsakad.Akad. Förhandl., 57(8):919-1038.

Cleve, P.T., and Grunow, A., 1880. Beiträge zur Kenntnis der arktischen Diatomeen. K. Sven. Vetenskapsakad. Handl., 17(2).

Cody, R.D., Levy, R.H., Harwood, D.M., and Sadler, P.M., 2008. Thinking outside the zone: high-resolution quantitative diatom biochronology for the Antarctic Neogene. Palaeogeogr., Palaeoclimatol., Palaeoecol., 260(12):92-121. doi:10.1016/j.palaeo.2007.08.020

Desikachary, T.V., and Sreelatha, P.M., 1989. Oamaru diatoms. Bibl. Diatomologica, 19.

Donahue, J.G., 1970. Diatoms as Quaternary biostratigraphic and paleoclimatic indicators in high latitudes of the Pacific Ocean [Ph.D. dissert.]. Columbia Univ., New York.

Ehrenberg, C.G., 1837. [Eine briefliche Nachricht des Hrn. Agassiz in Neuchatel] über den ebenfalls aus mikroskopischen Kiesel-Organismen gebildeten Polirschiefer von Oran in Africa. Ber. Verh. K. Preuss. Akad. Wiss. Berlin 1837:59-61.

Ehrenberg, C.G., 1838. Die Infusionsthierchen als vollkommene Organismen. Ein Blick in das tiefere organische Leben der Natur: Leipzig (Leopold Voss).

Ehrenberg, C.G., 1840a. Characteristik von 274 neuen Arten von Infusorien. Ber. Verh. K. Preuss. Akad. Wiss. Berlin, 1840:197-219.

Ehrenberg, C.G., 1840b. Über noch zahlreich jetzt lebende Thierarten der Kreidebildung und den Organismus der Polythalamien. Phys. Abh. K. Akad. Wiss. Berlin, 1840.

Ehrenberg, C.G., 1843. Verbreitung und Einfluß des mikroskopischen Lebens in Süd- und Nord-Amerika: ein Vortrag.Berlin (K. Akad. Wiss.)Abh. Preuss. Akad. Wiss. Berlin, Kl. Phys., 4:291-446.

Ehrenberg, C.G., 1844a. Einige vorläufige Resultate der Untersuchungen der von der Südpolreise des Captain Ross, sowie in den Herren Schayer und Darwin zugekommenen Materialien über das Verhalten des kleinsten Lebens in den Ozeanen und den größten bisher zugänglichen Tiefen des Weltmeeres. Ber. Verh. K. Preuss. Akad. Wiss. Berlin, 1844:182-207.
Ehrenberg, C.G., 1844b. Mittheilung uber zwei neue Lager von Gebirgsmassen aus Infusonien als Meeres-Absatz in Nord-Amerika und eine Vergleichung derselben mit den organischen Kreide-Gebilden in Europa und Afrika. Ber. Verh. K. Preuss Akad. Wiss. Berlin, 1844:57-97.

Ehrenberg, C.G., 1854. Mikrogeologie: das Erden und Felsen schaffende Wirken des unsichtbar kleinen selbständigen Lebens auf der Erde: Leipzig (Verlag von Leopold Voss).

Expedition 317 Scientists, 2011a. Expedition 317 summary. In Fulthorpe, C.S., Hoyanagi, K., Blum, P., and the Expedition 317 Scientists, Proc. IODP, 317: Tokyo (Integrated Ocean Drilling Program Management International, Inc.). doi:10.2204/iodp.proc.317.101.2011

Expedition 317 Scientists, 2011b. Methods. In Fulthorpe, C.S., Hoyanagi, K., Blum, P., and the Expedition 317 Scientists, Proc. IODP, 317: Tokyo (Integrated Ocean Drilling Program Management International, Inc.). doi:10.2204/iodp.proc.317.102.2011

Expedition 317 Scientists, 2011c. Site U1352. In Fulthorpe, C.S., Hoyanagi, K., Blum, P., and the Expedition 317 Scientists, Proc. IODP, 317: Tokyo (Integrated Ocean Drilling Program Management International, Inc.). doi:10.2204/iodp.proc.317.104.2011

Fenner, J., Schrader, H.-J., and Wienigk, H., 1976. Diatom phytoplankton studies in the southern Pacific Ocean: composition and correlation to the Antarctic Convergence and its paleoecological significance. In Hollister, C.D., Craddock, C., et al., Init. Repts. DSDP, 35: Washington, DC (U.S. Govt. Printing Office), 757-813. doi:10.2973/dsdp.proc.35.app3.1976

Fenner, J.M., 1991a. Late Pliocene-Quaternary quantitative diatom stratigraphy in the Atlantic sector of the Southern Ocean. In Ciesielski, P.F., Kristoffersen, Y., et al., Proc. ODP, Sci. Results, 114: College Station, TX (Ocean Drilling Program), 97-121. doi:10.2973/

odp.proc.sr.114.133.1991

Fenner, J.M., 1991b. Taxonomy, stratigraphy, and paleoceanographic implications of Paleocene diatoms. In Ciesielski, P.F., Kristoffersen, Y., et al., Proc. ODP, Sci. Results, 114: College Station, TX (Ocean Drilling Program), 123-154. doi:10.2973/ odp.proc.sr.114.137.1991

Frenguelli, J., 1949. Diatomeas fósiles de los yacimientos chilenos de Tiltil y Mejillones. Darwiniana, 9(1):97-157.

Fryxell, G.A., 1977. Thalassiosira australis Peragallo and Thalassiosira lentiginosa (Janisch) G. Fryxell, comb. nov.: two Antarctic diatoms (Bacillariophyceae). Phycologia, 16(1):95-104.

Fryxell, G.A., and Hasle, G.R., 1972. Thalassiosira eccentrica (Ehrenb.) Cleve, T. symmetrica sp. nov., and some related Centric diatoms. J. Phycol., 8(4):297-317. doi:10.1111/j.1529-8817.1972.tb04044.x

Gersonde, R., 1991. Taxonomy and morphostructure of late Neogene diatoms from Maud Rise (Antarctic Ocean). Polarforschung, 59(3):141-171. http:// epic.awi.de/28264/1/Polarforsch1989_3_4.pdf

Gersonde, R., and Bárcena, M.A., 1998. Revision of the upper Pliocene: Pleistocene diatom biostratigraphy for the northern belt of the Southern Ocean. Micropaleontology, 44(1):84-98. doi:10.2307/1486086 
Gersonde, R., and Burckle, L.H., 1990. Neogene diatom biostratigraphy of ODP Leg 113, Weddell Sea (Antarctic Ocean). In Barker, P.F., Kennett, J.P., et al., Proc. ODP, Sci. Results, 113: College Station, TX (Ocean Drilling Program), 761-789. doi:10.2973/ odp.proc.sr.113.126.1990

Gombos, A.M., Jr., 1977. Paleogene and Neogene diatoms from the Falkland Plateau and Malvinas Outer Basin: Leg 36, Deep Sea Drilling Project. In Barker, P.F., Dalziel, I.W.D., et al., Init. Repts. DSDP, 36: Washington, DC (U.S. Govt. Printing Office), 575-687. doi:10.2973/ dsdp.proc.36.111.1977

Gombos, A.M., Jr., and Ciesielski, P.F., 1983. Late Eocene to early Miocene diatoms from the southwest Atlantic. In Ludwig, W.J., Krasheninnikov, V.A., et al., Init. Repts. DSDP, 71: Washington, DC (U.S. Govt. Printing Office), 583-634. doi:10.2973/dsdp.proc.71.124.1983

Gran, H.H., 1900. Diatomaceae from the ice-floes and plankton of the Arctic Ocean. In Nansen, F. (Ed.), Norwegian North Polar Expedition 1893-1896, Scientific Results: Oslo (Jacob Dybwad, Christiania), 4(11):1-74.

Gregory, W., 1855. On a post-Tertiary lacustrine sand containing diatomaceous exuviae from Glenshira, near Inverness. Quat. J. Microscop. Sci., 3:30-43.

Gregory, W., 1856. On the post-Tertiary diatomaceous sand of Glenshire, Part II. Containing an account of a number of additional undescribed species. Trans. Microsc. Soc. London, 4:35-48.

Gregory, W., 1857. On new forms of marine Diatomaceae found in the Firth of Clyde and in Loch Fyne. Trans. $-R$. Soc. Edinburgh, 21:473-542.

Greville, R.K., 1866. Descriptions of new and rare diatoms. Series 20. Trans. Microsc. Soc. London, 14:121-130.

Grunow, A., 1862. Die österreischischen Diatomaceen, nebst Anschluss einiger neuen Arten van andern Lokalitaten und einer kritischen Uebersicht der bishen bekannten Gattungen und Arten. Verh. Zool.-Bot. Ges. Wien, 12:315-588.

Grunow, A., 1878. Algen und Diatomaceen aus dem Kaspischen Meere. In Schneider, O. (Ed.), Naturwissenschafte Beiträge zur Kenntniss der Kaukasusländer, auf Grund seiner Sammelbeute: Dresden (Isis Society), 98132.]

Grunow, A., 1880. Bemerkungen zu den Diatomeen von Finnmark, dem Karischen Meere und vom Jenissey nebst Vorarbeiten für Monographie der Gattungen Nitzschia, Achnanthes, Pleurosigma, Amphiprora, Plagiotropis, Hyalodiscus, Podosira und einiger Navicula-Gruppen. K. Sven. Vetenskapsakad. Handl., Bihang, 17(2):16-121.

Hajós, M., 1968. Die Diatomeen der Miozanen Ablagerungen des Matavvorlandes. Geol. Hung., Ser. Paleontol., 37.

Hajós, M., 1976. Upper Eocene and lower Oligocene diatomaceae, archaeomonadaceae, and silicoflagellatae in southwestern Pacific sediments, DSDP Leg 29. In Hollister, C.D., Craddock, C., et al., Init. Repts. DSDP, 35: Washington, DC (U.S. Govt. Printing Office), 817-883. doi:10.2973/dsdp.proc.35.29chap1.1976

Hajós, M., and Stradner, H., 1975. Late Cretaceous archaeomonadaceae, diatomaceae, and silicoflagellatae from the South Pacific Ocean, Deep Sea Drilling Project, Leg
29, Site 275. In Kennett, J.P., Houtz, R.E., et al., Init. Repts. DSDP, 29: Washington, DC (U.S. Govt. Printing Office), 913-1009. doi:10.2973/

dsdp.proc.29.126.1975

Hanna, G.D., and Grant, W.M., 1926. Expedition to the Revillagigedo Islands, Mexico, in 1925. II. Miocene marine diatoms from Maria Madre Islands, Mexico. Proc. Calif. Acad. Sci., 15:115-193.

Hargraves, P.E., 1968. Species distribution and composition of net plankton diatoms in the Pacific sector of the Antarctic Ocean [Ph.D. dissert.]. Coll. William and Mary, Virginia.

Harwood, D.M., and Maruyama, T., 1992. Middle Eocene to Pleistocene diatom biostratigraphy of Southern Ocean sediments from the Kerguelen Plateau, Leg 120. In Wise, S.W., Jr., Schlich, R., et al., Proc. ODP, Sci. Results, 120: College Station, TX (Ocean Drilling Program), 683-733. doi:10.2973/ odp.proc.sr.120.160.1992

Harwood, D.M., McMinn, A., and Quilty, P.G., 2000. Diatom biostratigraphy and age of the Pliocene Sørsdal Formation, Vestfold Hills, East Antarctica. Antarct. Sci., 12(4):443-462. doi:10.1017/S0954102000000535

Hasle, G.R., 1960. Phytoplankton and ciliate species from the tropical Pacific. Skr. Nor. Vidensk.-Akad., [Kl.] 1: Mat.Naturvidensk. Kl., 2:1-50.

Hasle, G.R., 1972. Fragilariopsis Hustedt as a section of the genus Nitzschia Hassall. Nova Hedwigia, Beih., 39:111120.

Hasle, G.R., 1993. Nomenclatural notes on marine planktonic diatoms. The family Bacillariaceae. Nova Hedwigia, Beih., 106:315-321.

Hasle, G.R., and Syvertsen, E.E., 1990. Family Biddulphiaceae. In Medlin, L.K., and Priddle, J. (Eds.), Polar Marine Diatoms: Cambridge (British Antarctic Survey), 129-131.

Hasle, G.R., and Syvertsen, E.E., 1996. Marine diatoms. In Tomas, C.R. (Ed.), Identifying Marine Diatoms and Dinoflagellates: San Diego (Academic Press), 5-386.

Heiden, H., and Kolbe, R.W., 1928. Die marinen Diatomeen der Deutschen Südpolar-Expedition 1901-1903. In von Drygalski, E. (Ed.), Deutsche Südpolar-Expedition, 1901-1903: Berlin (W. de Gruyter), 8:447-715.

Houk, V., and Klee, R., 2004. The stelligeroid taxa of the genus Cyclotella (Kützing) Brébisson (Bacillariophyceae) and their transfer into the new genus Discostella gen. nov. Diatom Res., 19(2):203-228. doi:10.1080/ 0269249X.2004.9705871

Hustedt, F., (1930) 1977. Die Kieselalgen Deutschlands, Österreichs und der Schweiz unter Berücksichtigung der übrigen Länder Europas sowie der angrenzenden Meeresgebiete (Vol. 1). In Rabenhorst, L. (Ed.), Die Kryptogamenflora von Deutschland, Österreich und der Schweiz: Leipzig (Akadademie Verlag). Reprint, Koenigstein (O. Koeltz Sci. Publ.).

Hustedt, F., 1952. Diatomeen aus der Lebensgemeinschaft der Buckelwals (Megaptera nodosa Bonn.). Arch. Hydrobiol., 46(2):286-298.

Hustedt, F., 1958. Diatomeen aus der Antarktis und dem Südatlantik. Deutsche Antarktische Expedition 1938/1939: 
Hamburg (Geographisch-kartographische Anstalt Mundus), 2:103-191.

Iwai, M., and Winter, D., 2002. Data report: taxonomic notes of Neogene diatoms from the western Antarctic peninsula: Ocean Drilling Program Leg 178. In Barker, P.F., Camerlenghi, A., Acton, G.D., and Ramsay, A.T.S. (Eds.), Proc. ODP, Sci. Results, 178: College Station, TX (Ocean Drilling Program), 1-57. doi:10.2973/ odp.proc.sr.178.239.2002

Jordan, R.W., Ligowski, L., Nöthig, E.-M., and Priddle, J., 1991. The diatom genus Proboscia in Antarctic waters. Diatom Res., 6(1):63-78. doi:10.1080/ 0269249X.1991.9705148

Jordan, R.W., and Priddle, J., 1991. Fossil members of the diatom genus Proboscia. Diatom Res., 6(1):55-61. doi:10.1080/0269249X.1991.9705147

Jørgensen, E.G., 1905. Diatoms in bottom samples from Lofoten and Vesteraalen. In Nordgaard, O. (Ed.), Hydrographical and Biological Investigations in Norwegian Fjords: Bergen (John Grieg), 195-245.

Jousé, A.P., 1959. The main phases in the development of the flora of marine diatoms in the far eastern seas of the U.S.S.R. at the end of the Tertiary, and during the Quaternary period. Bot. Zh. (S.-Peterburg, Russ. Fed.), 44(1):44-55.

Jousé, A.P., 1968. Species novae Bacillariophytorum in sedimentis fundi Oceani Pacifici et Maris Ochotensis inventae. Nov. Sist. Nizshikh Rast., 3:12-21.

Jousé, A.P., Koroleva, G.S., and Negaeva, G.A., 1962. Diatoms in the surface layer of sediment in the Indian sector of the Antarctic. Trudy Inst. Okeanol., Akad. Nauk SSSR, 61:19-92.

Karsten, G., 1905. Das Phytoplankton des Antarktischen Meeres nach dem Material der deutschen Tiefsee-Expedition, 1898-1899. In Chun, C. (Ed.), Wissenschaftliche Ergebnisse der Deutschen Tiefsee-Expedition auf dem Dampfer "Valdivia" 1898-1899: Jena (Gustav Fischer), 2(1).

Koizumi, I., 2010. Revised diatom biostratigraphy of DSDP Leg 19 drill cores and dredged samples from the subarctic Pacific and Bering Sea. JAMSTEC Rep. Res. Dev., 10:121. doi:10.5918/jamstecr.10.1

Koizumi, I., Irino, T., and Oba, T., 2004. Paleoceanography during the last 150 kyr off central Japan based on diatom floras. Mar. Micropaleontol., 53(3-4):293-365. doi:10.1016/j.marmicro.2004.06.004

Kützing, F.T., 1844. Die kieselschaligen Bacillarien oder Diatomeen: Nordhausen (W. Köhne).

Lee, Y.G., 1993. The marine diatom genus Chaetoceros Ehrenberg flora and some resting spores of the Neogene Yeonil Group in the Pohang Basin, Korea. J. Paleontol. Soc. Korea, 9(1):24-52.

Lisiecki, L.E., and Raymo, M.E., 2005. A Pliocene-Pleistocene stack of 57 globally distributed benthic $\delta^{18} \mathrm{O}$ records. Paleoceanography, 20(1):PA1003. doi:10.1029/ 2004PA001071

Lohman, K.E., 1941. Geology and biology of North Atlantic deep-sea cores between Newfoundland and Ireland, Part 3. Diatomaceae. U.S. Geol. Surv. Prof. Pap., 196B:5593. http://pubs.er.usgs.gov/publication/pp196B
Mahood, A.D., and Barron, J.A., 1996a. Comparative ultrastructure of two closely related Thalassiosira species: Thalassiosira vulnifica (Gombos) Fenner and T. fasciculata Harwood et Maruyama. Diatom Res., 11:283-295.

Mahood, A.D., and Barron, J.A., 1996b. Late Pliocene diatoms in a diatomite from Prydz Bay, East Antarctica. Micropaleontology, 42(3):285-302. doi:10.2307/1485876

Manguin, L., 1915. Phytoplancton de l'Antarctique, Expédition du 'Pourquoi Pas?'. In Deuxième Expédition Antarctique Française (1908-1910) commandée par le Dr. Jean Charcot, Sciences Naturelles: Documents Scientifiques, Botanique: Paris (Masson et Cie).

McCollum, D.W., 1975. Diatom stratigraphy of the Southern Ocean. In Hayes, D.E., Frakes, L.A., et al., Init. Repts. DSDP, 28: Washington, DC (U.S. Govt. Printing Office), 515-571. doi:10.2973/dsdp.proc.28.112.1975

McMinn, A., Howard, W.R., and Roberts, D., 2001. Late Pliocene dinoflagellate cyst and diatom analysis from a high resolution sequence in DSDP Site 594, Chatham Rise, south west Pacific. Mar. Micropaleontol., 43(34):207-221. doi:10.1016/S0377-8398(01)00026-3

Medlin, L.K., and Sims, P.A., 1993. The transfer of Pseudoeunotia doliolus to Fragilariopsis. Nova Hedwigia, 106:323-334.

Mereschkowsky, C., 1902. Liste des Diatomées de la mer Noire: St. Petersburg (Scripta Botanica), 19:51-88.

O'Meara, E., 1877. On the diatomaceous gatherings made at Kerguelen's Land by H. N. Moseley, M.A., H.M.S. Challenger. J. Linn. Soc. London, Bot., 15(82):55-63.

Ostenfeld, C.H., 1900. Plankton in 1899. In Wandel, C.F., Knudsen, M., and Ostenfeld, C.H., (Eds.), Iagttagelser over Overfladevandets Temperatur, Saltholdighed og Plankton paa islandske og grønlandske Skibsrouter i 1899:Kobenhavn (I. Kommission hos G.E.C. Gad.), 43-93.

Pritchard, A., 1861. A History of the Infusoria (4th ed.): London (Whittaker and Co.).

Rattray, J., 1890. A revision of the genus Actinocyclus Ehr. J. Quekett Microsc. Club, 4:137-212.

Rines, J.E.B., and Hargraves, P.E., 1988. The Chaetoceros Ehrenberg (Bacillariophyceae) flora of Narrangansett Bay, Rhode Island, U.S.A. Bibl. Phycol., 79.

Sancetta, C., 1982. Distribution of diatom species in surface sediments of the Bering and Okhotsk Seas. Micropaleontology, 28(3):221-257. doi:10.2307/1485181

Schmidt, A., 1878. Atlas der Diatomaceen-kunde: Aschersleben, Germany (Verlag von Ludwig Sievers), II.

Schrader, H.-J., 1976. Cenozoic planktonic diatom biostratigraphy of the southern Pacific Ocean. In Hollister, C.D., Craddock, C., et al., Init. Repts. DSDP, 35: Washington, DC (U.S. Govt. Printing Office), 605-671. doi:10.2973/dsdp.proc.35.136.1976

Schrader, H.-J., and Fenner, J., 1976. Norwegian Sea Cenozoic diatom biostratigraphy and taxonomy. In Talwani, M., Udintsev, G., et al., Init. Repts. DSDP, 38: Washington, DC (U.S. Govt. Printing Office), 921-1099. doi:10.2973/dsdp.proc.38.130.1976

Simonsen, R., 1979. The diatom system: ideas on phylogeny. Bacillaria, 2:9-71. 
Simonsen, R., 1982. Notes on the diatom genus Charcotia M. Peragallo. Bacillaria, 5:101-116.

Smith, W., 1853. A Synopsis of British Diatomaceae: London (John Van Voorst).

Sundström, B.G., 1986. The marine diatom genus Rhizosolenia: a new approach to the taxonomy [Ph.D. dissert.]. Univ. Gothorum Carolinae, Sweden.

Suto, I., 2003. Taxonomy of the marine diatom resting spore genera Dicladia Ehrenberg, Monocladia gen. nov. and Syndendrium Ehrenberg and their stratigraphic significance in Miocene strata. Diatom Res., 18(2):331-356. doi:10.1080/0269249X.2003.9705596

Suto, I., 2004a. Coronodiscus gen. nov., a new diatom resting spore genus from the North Pacific and Norwegian Sea. Diatom, 20-21:95-104.

Suto, I., 2004b. Dispinodiscus gen. nov., a new diatom resting spore genus from the North Pacific and Norwegian Sea. Diatom, 20-21:79-94.

Suto, I., 2004c. Fossil marine diatom resting spore morphogenus Gemellodiscus gen. nov. in the North Pacific and Norwegian Sea. Paleontol. Res., 8(4):255-282. doi:10.2517/prpsj.8.255

Suto, I., 2004d. Fossil marine diatom resting spore morpho-genus Xanthiopyxis Ehrenberg in the North Pacific and Norwegian Sea. Paleontol. Res., 8(4):283-310. doi:10.2517/prpsj.8.283

Suto, I., 2004e. Taxonomy of the diatom resting spore form genus Liradiscus Greville and its stratigraphic significance. Micropaleontology, 50(1):59-79. doi:10.2113/ 50.1 .59

Suto, I., 2005a. Taxonomy and biostratigraphy of the fossil marine diatom resting spore genera Dicladia Ehrenberg, Monocladia Suto and Syndendrium Ehrenberg in the North Pacific and Norwegian Sea. Diatom Res., 20(2):351-374. doi:10.1080/0269249X.2005.9705642

Suto, I., 2005b. Vallodiscus gen. nov., a new fossil resting spore morpho-genus related to the marine diatom genus Chaetoceros (Bacillariophyceae). Phycol. Res., 53(1):11-29.

Suto, I., 2006a. Taxonomy of the fossil marine diatom resting spore morpho-genera Xanthioisthmus Suto gen. nov. and Quadrocistella Suto gen. nov. in the North Pacific and Norwegian Sea. J. Micropalaeontol., 25(1):3-22. doi:10.1144/jm.25.1.3
Suto, I., 2006b. The explosive diversification of the diatom genus Chaetoceros across the Eocene/Oligocene and Oligocene/Miocene boundaries in the Norwegian Sea. Mar. Micropaleontol., 58(4):259-269. doi:10.1016/j.marmicro.2005.11.004

Suto, I., 2006c. Truncatulus gen. nov., a new fossil resting spore morphogenus related to the marine diatom genus Chaetoceros (Bacillariophyceae). Phycologia, 45(5):581601. doi:10.2216/04-91.1

Suto, I., 2007. The Oligocene and Miocene record of the diatom resting spore genus Liradiscus Greville in the Norwegian Sea. Micropaleontology, 53(1-2):145-159. doi:10.2113/gsmicropal.53.1-2.145

Suto, I., Jordan, R.W., and Watanabe, M., 2009. Taxonomy of middle Eocene diatom resting spores and their allied taxa from the Central Arctic Basin. Micropaleontology, 55(2-3):259-312.

Tempère, J., and Peragallo, H., 1908. Diatomées du Monde Entier (Ed. 2): Gironde (J. Tempère, Arcachon).

Van Heurck, H., 1880-1885. Synopsis des Diatomées de Belgique. Atlas (1880-1881), Texte (1885). Anvers (Van Hoorst).

Van Heurck, H., 1896. A Treatise on the Diatomaceae. London (William Wesley \& Son).

Van Heurck, H., 1909. Diatomées. In Expédition Antarctique Belge-Résultats du Voyage du S.Y. Belgica en 1897-1899: Botaniques et Zoologie:. Anvers (J. E. Buschmann).

Wallich, G.C., 1860. On the siliceous organisms found in the digestive cavities of the Salpae, and their relation to the flint nodules of the Chalk Formation. Trans. Microsc. Soc. London, 8:36-55.

Yanagisawa, Y., and Akiba, F., 1998. Refined Neogene diatom biostratigraphy for the northwest Pacific around Japan, with an introduction of code numbers for selected diatom biohorizons. Chishitsugaku Zasshi, 104(6):395-414. doi:10.5575/geosoc.104.395

Zielinski, U., and Gersonde, R., 2002. Plio-Pleistocene diatom biostratigraphy from ODP Leg 177, Atlantic sector of the Southern Ocean. Mar. Micropaleontol., 45:225268. doi:10.1016/S0377-8398(02)00031-2

Initial receipt: 5 August 2012

Acceptance: 1 May 2013

Publication: 5 August 2013

MS 317-202 
Figure F1. Map of the Canterbury Basin on the eastern margin of South Island, New Zealand. Inset map shows Expedition 317 site locations, with primary and alternate sites marked in red and yellow, respectively.

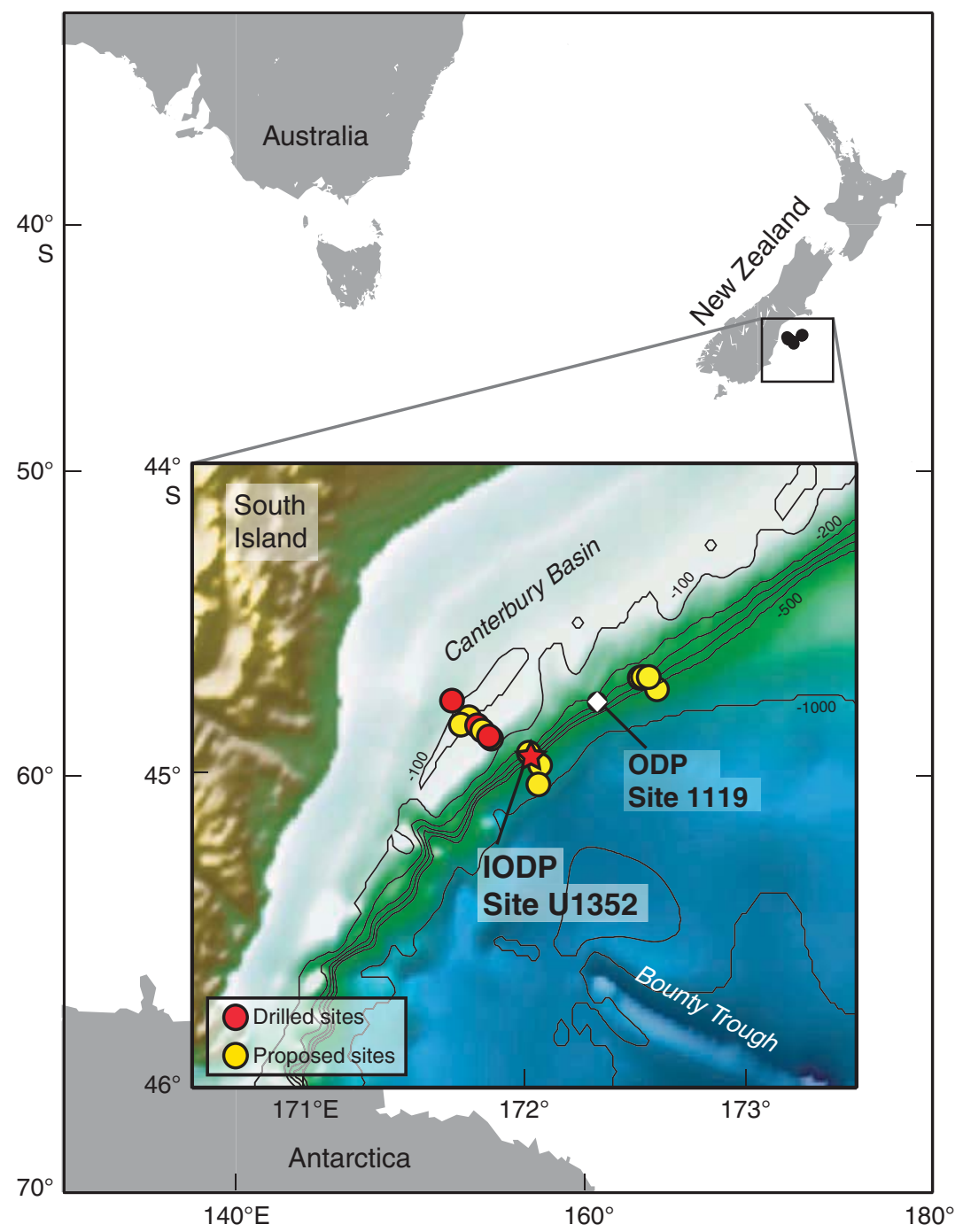


Figure F2. Diatom and resting spore ranges and abundances $/ 320 \mathrm{~mm}^{2}$ coverslip based on onshore analysis data, Hole U1352B. Ages were mainly controlled by the results of calcareous nannoplankton bioevents with benthic and planktonic foraminifers (see the "Methods" chapter [Expedition 317 Scientists, 2011b]).

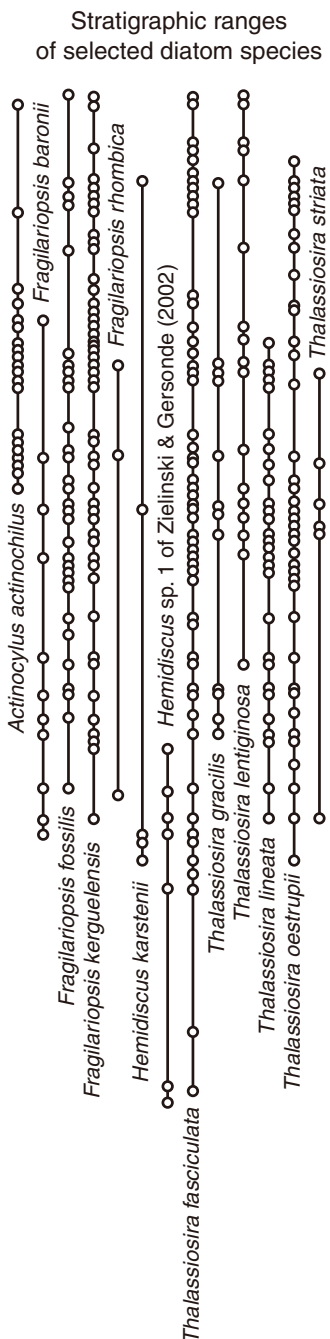

Microfossil bioevents
determined in offshore work

Age (Ma) Marker Species

0.29 FO Emiliania huxleyi (CN)

$\sim 0.40$ LO Proxifrons advena (BF)
0.60 LO Bolivinita pliozea (BF)

(CN) E

0.34 FO Hirsutella hirsuta (PF)

0.91 LCO Reticulofenestra asanoi (CN) [

1.14 FCO Reticulofenestra asanoi (CN)

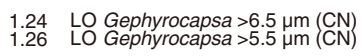

1.34 LO Helicosphaera sellii (CN)

1.56 FO Gephyrocapsa >5.5 $\mu \mathrm{m}$ (CN)

1.69 FO Gephyrocapsa $>4$ um (CN)

$<2.4$ FO Truncorotalia crassula (PF)

$>3.09$
2.78 LO Truncorotallia crassaconica? (PF)

3.62-5.30 LO Haeuslerella morgani (BF)

FO: First occurrence FCO: First common

LO: Last occurrence

LCO: Last common occurrence

$\mathrm{CN}$ : Calcareous nannoplankton

PF: Planktonic foraminife

\section{Hole U1352B}

Diatom vegetative cells

Core Lith.

Diatom resting spores
(N/coverslip)

Chaetoceros resting

spores per 100

vegetative valves $(N)$

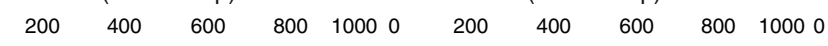

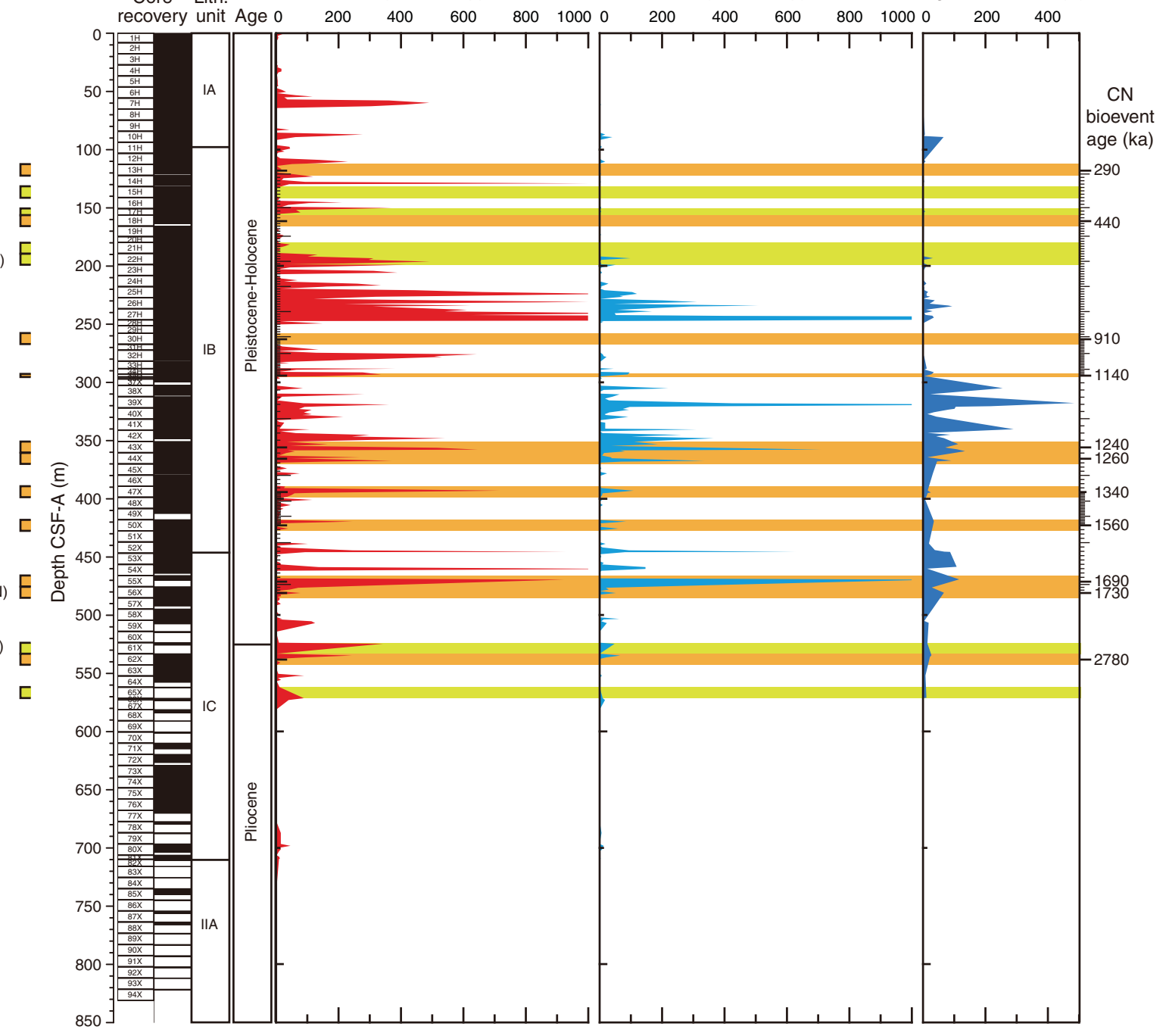


Figure F3. Marine, littoral to neritic, and freshwater diatom abundances and percentages of warm-water vs. cold-water diatoms. A total of 111 slides with better preserved and abundant diatoms ( $\geq 50$ valves/slide) were selected and used for paleoceanographical analysis. Benthic $\delta^{18} \mathrm{O}$ records and marine isotope stages (MIS) are after Lisiecki and Raymo (2005). Pink highlights indicate warm periods. Regression curves (red and blue lines on each figure) were drawn by spline smoothing.
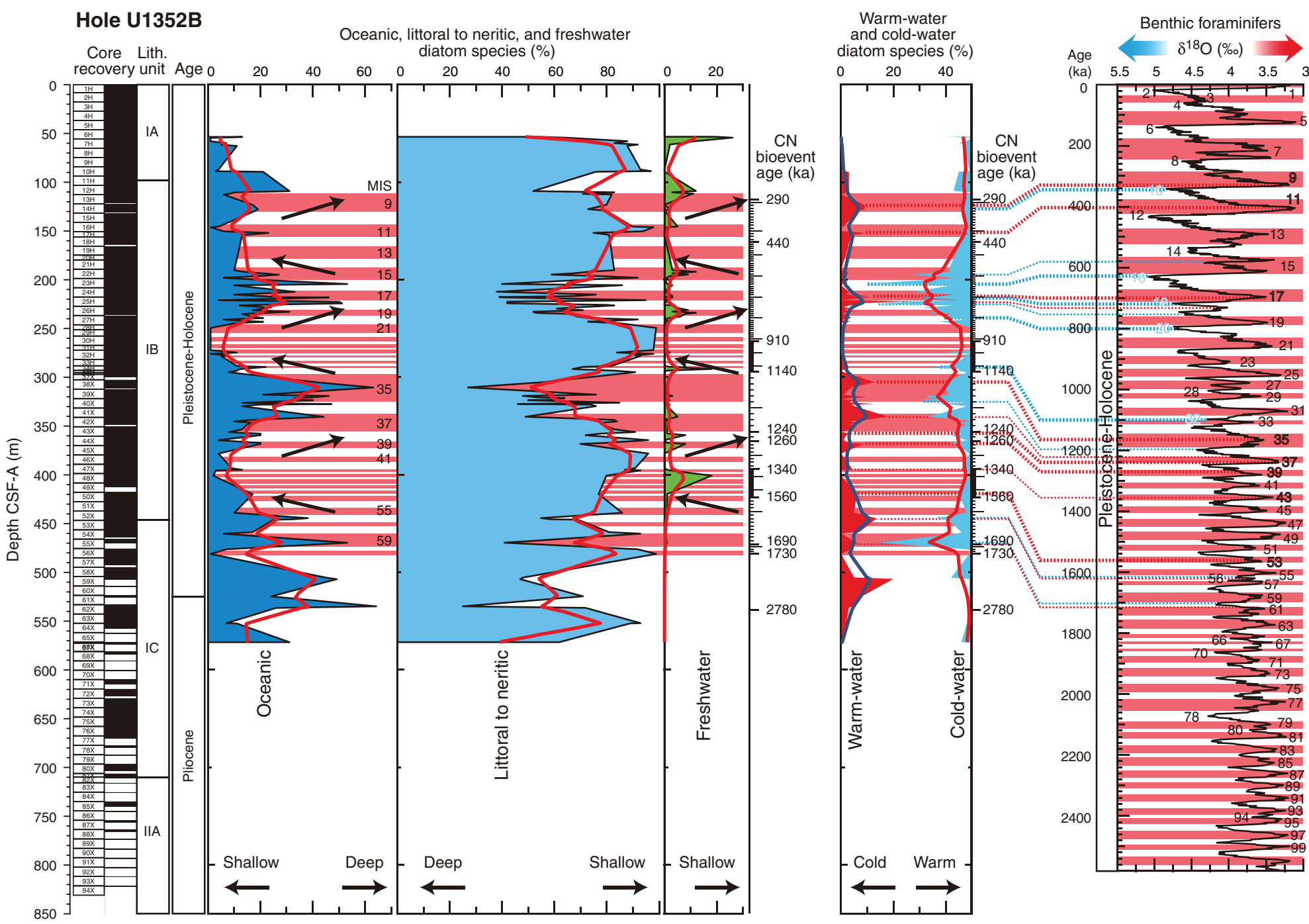
Table T1. Diatoms, Hole U1352B. This table is available in an oversized format. 
Plate P1. Light microscope images of marine diatoms, Hole U1352B. 1, 2. Actinocyclus actinochilus (Ehrenberg) Simonsen (Sample 317-U1352B-26H-6W, 25-26 cm). 3-14. Actinocyclus curvatulus Janisch in Schmidt: $(3,4)$ Sample 317-U1352B-13H-3W, 102-103 cm; $(5,6)$ Sample 38X-6W, 25-26 cm; $(7,8)$ Sample 41X-7W, 30-31 $\mathrm{cm}$; $(9,10)$ Sample $27 \mathrm{H}-1 \mathrm{~W}, 100-101 \mathrm{~cm} .(11,12)$ Sample 14H-4W, 100-101 cm; $(13,14)$ Sample 42X-3W 105-106 cm. 15, 16. Actinocyclus ingens Rattray (Sample 317-U1352B-35H-2W, 52-53 cm). 17-22. Actinocyclus sp. A: $(17,18)$ Sample 317-U1352B-62X-3W, 24-25 cm; $(19,20)$ Sample 48X-2W, 80-81 cm; $(21,22)$ Sample 45X-6W, 85-86 cm. 23, 24. Actinocyclus sp. B (Sample 317-U1352B-14H-1W, 100-101 cm). 25-28. Actinoptychus bipunctatus Lohman: $(25,26)$ Sample 317-U1352B-27H-4W, 100-101 cm; $(27,28)$. Sample 35H-2W, 52-53 cm. 29-34. Actinoptychus spp.: (29, 30) Sample 317-U1352B-27H-4W, 100-101 cm; (31, 32) Sample 39X-6W, 100-101 cm; $(33,34)$. Sample 43X-5W, 105-106 cm. 35, 36. Asteromphalus hyalinus Karsten (Sample 317U1352B-59X-1W, 99-100 cm). 37, 38. Eucampia antarctica (Castracane) Manguin (Sample 317-U1352B-26H$5 \mathrm{~W}, 100-101 \mathrm{~cm})$.

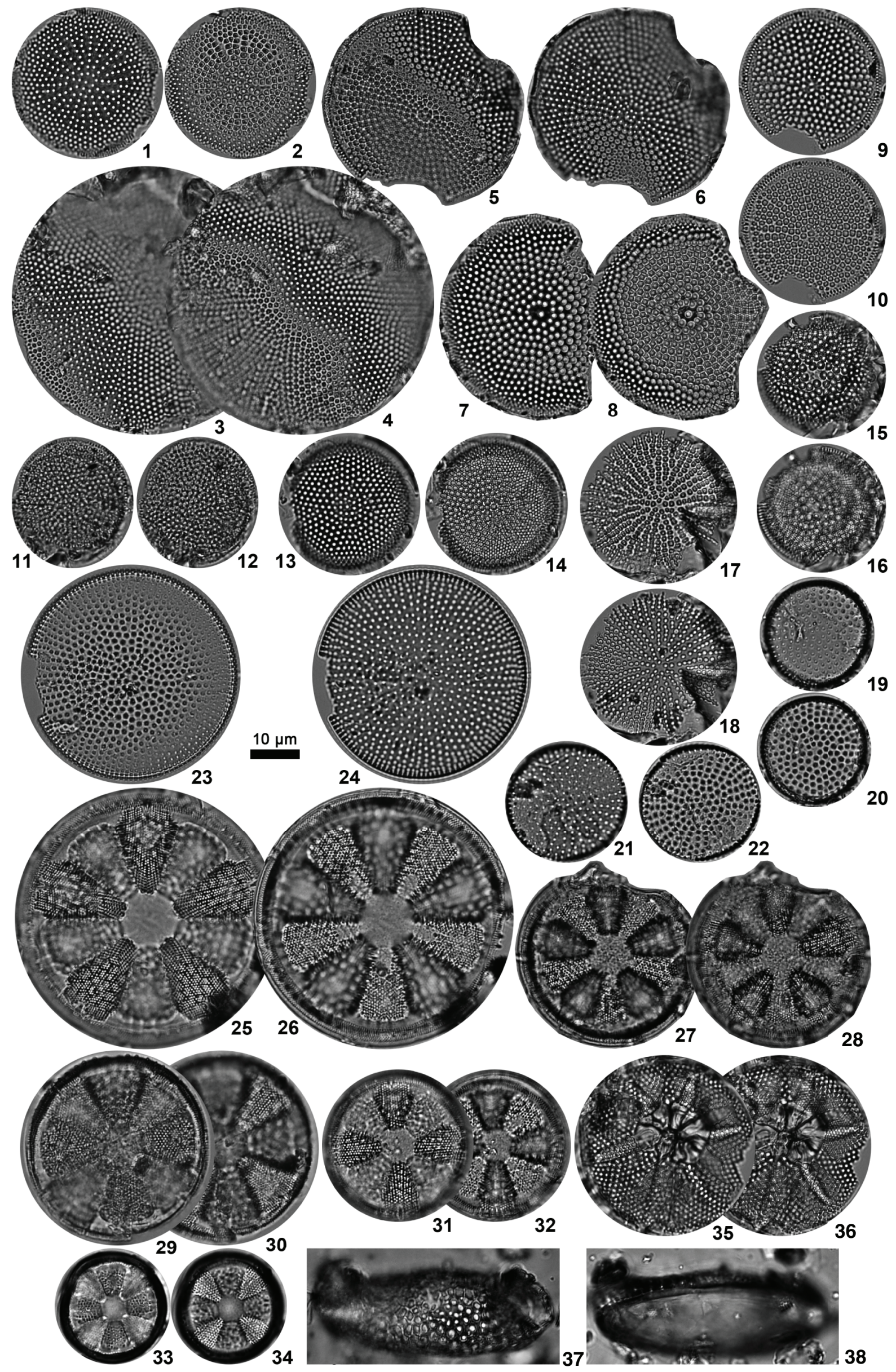


Plate P2. Light microscope images of marine diatoms, Hole U1352B. 1, 2. Coscinodiscus asteromphalus Ehrenberg: (1) Sample 317-U1352B-55X-3W, 72-73 cm; (2) Sample 27H-5W, 25-26 cm. 3, 4. Coscinodiscus marginatus Ehrenberg (Sample 317-U1352B-63X-7W, 42-43 cm). 5, 6. Coscinodiscus radiatus Ehrenberg (Sample 317-U1352B-24H-4W, 79-80 cm). 7, 8. Coscinodiscus sp. (Sample 317-U1352B-50X-2W, 33-34 cm). 9, 10. Hemidiscus cuneiformis Wallich (Sample 317-U1352B-7H-5W, 97-98 cm). 11-14. Hemidiscus karstenii Jousé in Jousé et al.: $(11,12)$. Sample 317-U1352B-63X-7W, 42-43 cm; $(13,14)$ Sample 62X-3W, 24-25 cm. 15-18. Hemidiscus sp. 1 sensu Zielinski and Gersonde $(2002):(15,16)$ Sample 317-U1352B-80X-2W, 25-26 cm; $(17,18)$ Sample 55X-3W, 72-73 cm. 19, 20. Thalassiosira delicatula Hustedt (Sample 317-U1352B-34H-1W, 4-5 cm). 21-23. Thalassiosira eccentrica (Ehrenberg) Cleve emend. Fryxell et Hasle: (21) Sample 317-U1352B-16H-7W, 24-25 cm; $(22,23)$ Sample 10H-4W, 100-101 cm. 24, 25. Thalassiosira fasciculata Harwood et Maruyama (Sample 317-U1352B-41X-7W, 30-31 cm). 26, 27. Thalassiosira gracilis (Karsten) Hustedt (Sample 317-U1352B12H-7W, 36-37 cm). 28, 29. Thalassiosira lentiginosa (Janisch in Schmidt) Fryxell (Sample 317-U1352B-6H-5W, 119-120 cm). 30-33. Thalassiosira lineata Jousé (Sample 317-U1352B-50X-6W, 31-32 cm). (Plate shown on next page.) 
Plate P2 (continued). (Caption shown on previous page.)

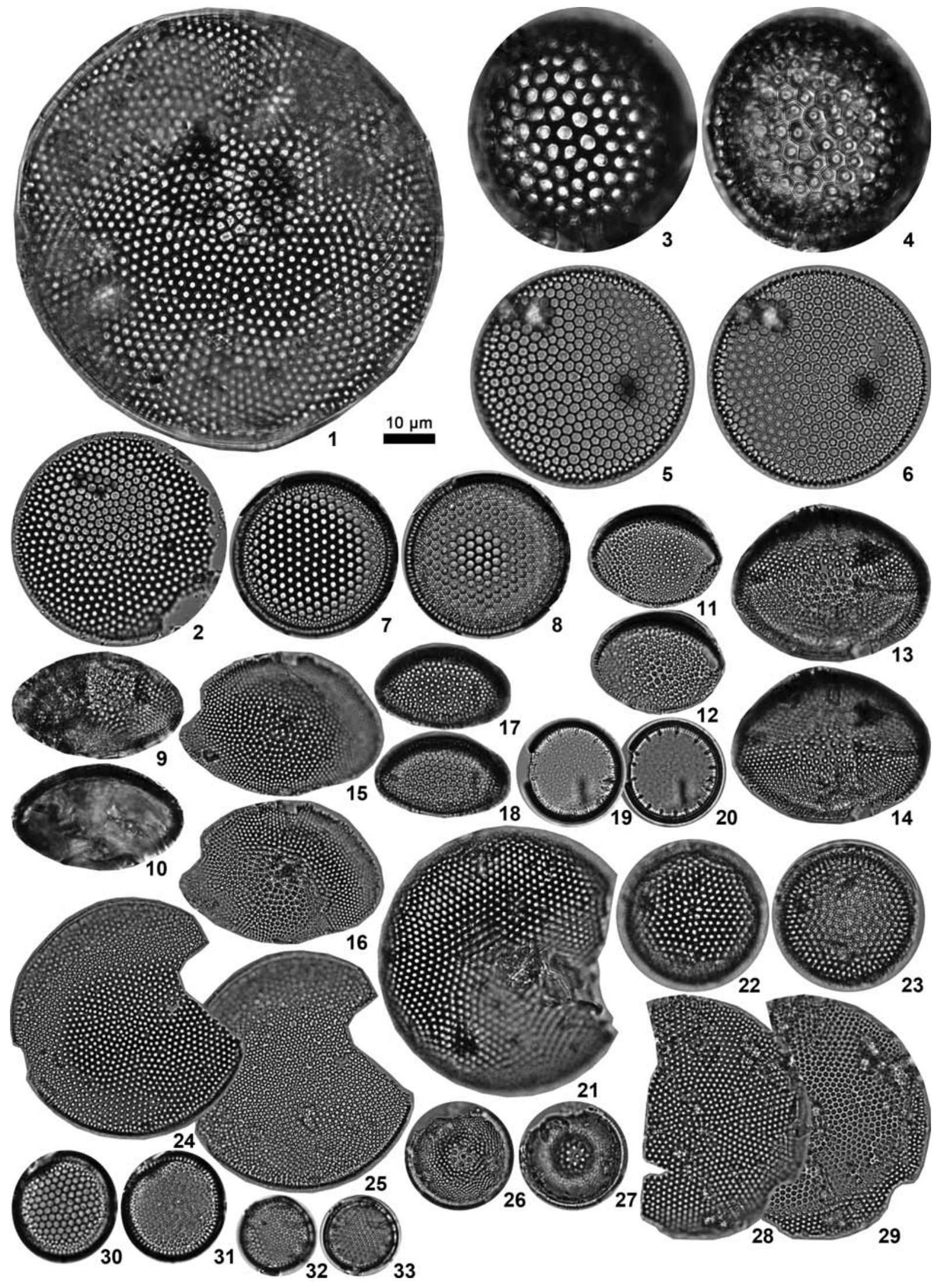


Plate P3. Light microscope images of marine diatoms, Hole U1352B. 1-4. Fragilariopsis barronii (Gersonde) Gersonde et Bárcena: $(1,2)$ Sample 317-U1352B-43X-2W, 105-106 cm; $(3,4)$ Sample 59X-1W, 99-100 cm. 5-10. Fragilariopsis barronii/kerguelensis transitional form of Zielinski and Gersonde: $(5,6)$ Sample 317-U1352B32H-2W, 80-81 cm; $(7,8)$ Sample 13H-6W, 32-33 cm; $(9,10)$ Sample 43X-4W, 105-106 cm. 11-16. Fragilariopsis cylindrica (Burckle) Censarek et Gersonde: $(11,12)$ Sample 317-U1352B-42X-4W, 100-101 cm; (13-16) Sample 59X-2W, 121-122 cm. 17, 18. Fragilariopsis doliolus (Wallich) Medlin et Sims (Sample 317-U1352B-43X-1W, 26$27 \mathrm{~cm}$ ). 19-22. Fragilariopsis fossilis (Frenguelli) Medlin et Sims (Sample 317-U1352B-39X-5W, 99-100 cm). 23-38. Fragilariopsis kerguelensis (O'Meara) Hustedt: $(23,24)$ Sample 317-U1352B-21H-2W, 35-36 cm; $(25,26)$ Sample 39X-5W, 99-100 cm; $(27,28)$ Sample 52X-6W, 104-105 cm; $(29,30)$ Sample 14H-6W, 7-8 cm; $(31,32$, 37, 38) Sample 317-U1352B-22H-5W, 39-40 cm; (33-36) Sample 55X-3W, 72-73 cm. 39, 40. Fragilariopsis rhombica (O'Meara) Hustedt (Sample 317-U1352B-26H-2W, 100-101 cm). 41, 42. Nitzschia bicapitata Cleve (Sample 317-U1352B-39X-5W, 99-100 cm). 43-48. Nitzschia spp.: (43, 44) Sample 317-U1352B-50X-2W, 33$34 \mathrm{~cm}$; $(45,46)$ Sample 38H-6W, 25-26 cm; $(47,48)$ Sample 39X-5W, 99-100 cm. 49, 50. Pinnularia sp. (Sample 317-U1352B-27H-1W, 100-101 cm). 51, 52. Proboscia alata (Brightwell) Sundström (Sample 317-U1352B-26H-4W, 100-101 cm). 53, 54. Proboscia barboi (Brun) Jordan et Priddle (Sample 317-U1352B-59X-1W, 99-100 cm). 55, 56. Proboscia curvirostris (Jousé) Jordan et Priddle (Sample 317-U1352B-40X-5W, 25-26 cm). 57, 58. Pseudodimerogramma sp. (Sample 317-U1352B-50X-4W, 33-34 cm). 59, 60. Pseudonitzschia turgidula (Hustedt) Hasle (Sample 317-U1352B-12H-4W, 130-131 cm). 61, 62. Pterotheca aculeifera Grunow in Van Heurck (hyaline type, Sample 317-U1352B-45X-4W, 105-106 cm). 63-68. Rhizosolenia hebetata Bailey: (63, 64) Sample 317-U1352B66X-1W, 10-11 cm; $(65,66)$ Sample 21H-5W, 46-47 cm; $(67,68)$ Sample 23H-4W, 110-111 cm. 69-74. Rhizosolenia polydactyla Castracane: $(69,70)$ Sample 317-U1352B-39X-7W, 15-16 cm; $(71,72)$ Sample 40X-2W, 25-26 $\mathrm{cm}$; $(73,74)$ Sample $64 \mathrm{X}-1 \mathrm{~W}, 31-32 \mathrm{~cm} .75-78$. Thalassiothrix longissima Cleve et Grunow in Grunow: $(75,76)$ Sample 317-U1352B-23H-3W, 110-111 cm; (77, 78) Sample 24H-6W, 110-111 cm. 79, 80. Tropidoneis sp. (Sample 317-U1352B-42X-5W, 100-101 cm). (Plate shown on next page.) 
Plate P3 (continued). (Caption shown on previous page.)

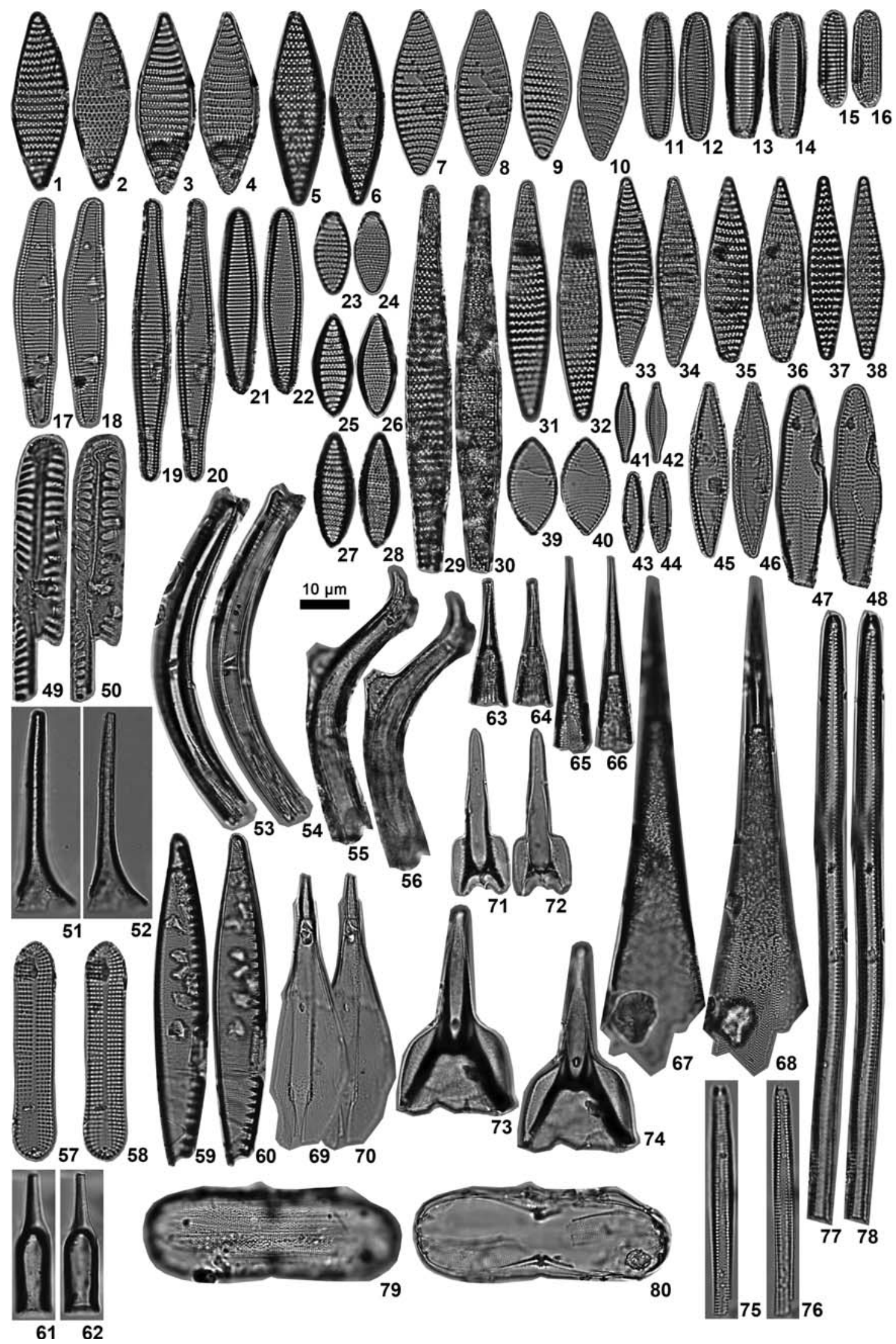


Plate P4. Light microscope images of marine diatoms, Hole U1352B. Scale bars $=10 \mu \mathrm{m}$ (left for figures 33, 34; right for others). 1-10. Thalassiosira oestrupii (Ostenfeld) Proschkina-Lavrenko ex Hasle: $(1,2)$ Sample 317 U1352B-17H-1W, 115-116 cm; (3, 4) Sample 17H-2W, 114-115 cm; $(5-8)$ Sample 38X-2W, 99-100 cm; $(9,10)$ Sample 56X-1W, 100-101 cm. 11, 12. Thalassiosira striata Harwood et Maruyama (Sample 317-U1352B-27H1W, 100-101 cm). 13-26. Thalassiosira sp. d of Fenner et al. (1976): (13, 14, 21, 22) Sample 317-U1352B-42X5W, 100-101 cm; $(15,16)$ Sample 41X-2W, 104-105 cm; $(17,18)$ Sample 28H-2W, 25-26 cm; $(19,20)$ Sample 13H-1W, 124-125 cm; (23-26) Sample 25H-1W, 25-26 cm. 27-30. Thalassiosira spp.: $(27,28)$ Sample 317U1352B-40X-6W, 25-26 cm; (29, 30) Sample 26H-6W, 25-26 cm. 31, 32. Thalassiosira oliverana (O'Meara) Sournia (Sample 317-U1352B-23H-4W, 110-111 cm). 33, 34. Triceratium spp. (Sample 317-U1352B-1H-1W, 60$61 \mathrm{~cm})$. 35-42. Genus et species indet.: $(35,36,39,40)$ Sample 317-U1352B-26H-2W, 100-101 cm; $(37,38)$ Sample 26H-5W, 100-101 cm; $(41,42)$ Sample 27H-1W, 100-101 cm. (Plate shown on next page.) 
Plate P4 (continued). (Caption shown on previous page.)
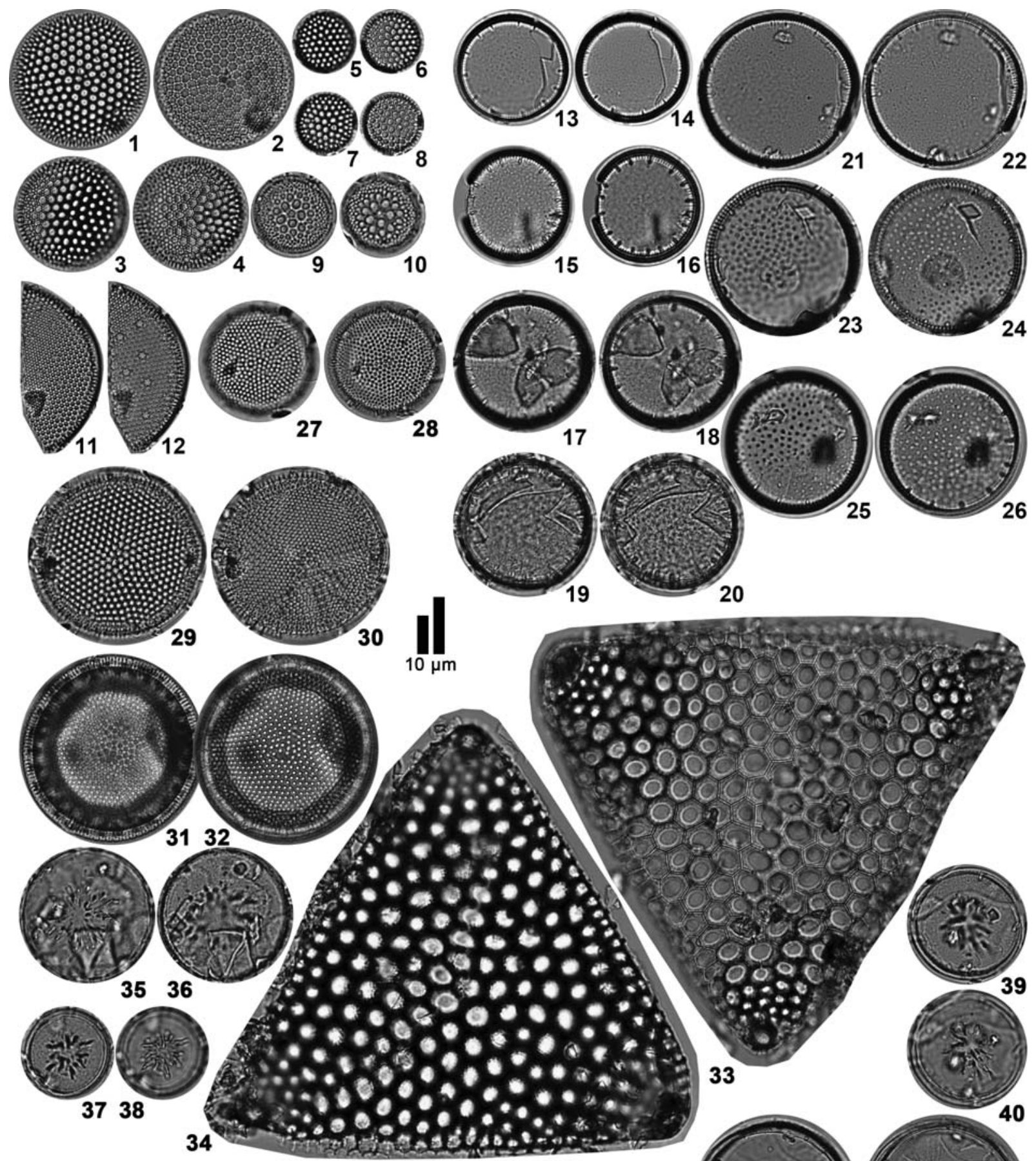

33

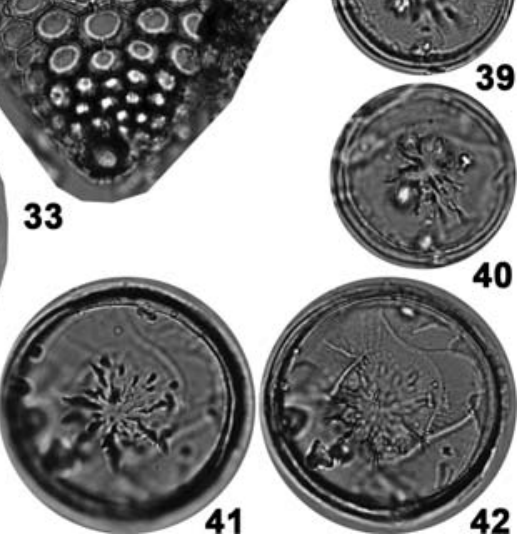


Plate P5. Light microscope images of littoral to neritic diatoms, Hole U1352B. 1-10. Actinoptychus senarius (Ehrenberg) Ehrenberg: $(1,2)$ Sample 317-U1352B-17H-3W, 26-27 cm; $(3,4,9,10)$ Sample 17H-2W, 114-115 cm; $(5,6)$ Sample 16H-7W, 24-25 cm; $(7,8)$ Sample 50X-6W, 31-32 cm. 11-16. Hyalodiscus spp.: $(11,12)$ Sample 317-U1352B-16H-4W, 36-37 cm; $(13,14)$ Sample 64X-1W, 31-32 cm; $(15,16)$ Sample 25H-6W, 50-51 cm. 17-23. Paralia sulcata (Ehrenberg) Cleve: (17) Girdle view (Sample 317-U1352B-12H-7W, 36-37 cm); $(18,19)$ Sample 4H-1W, 91-92 cm; (20-23) Sample 57X-4W, 100-101 cm.

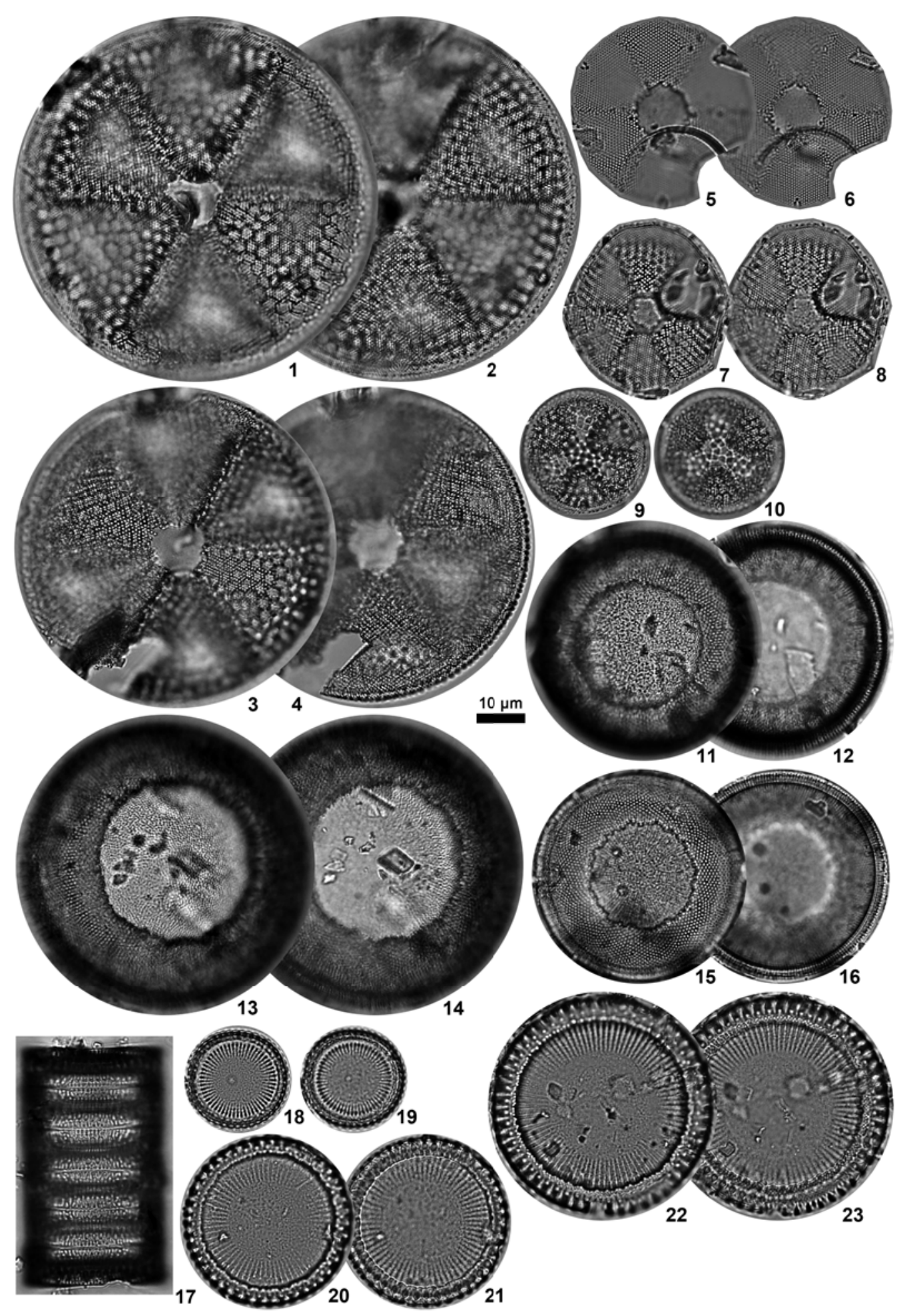


Plate P6. Light microscope images of littoral to neritic diatoms, Hole U1352B. Scale bars $=10 \mu \mathrm{m} . \mathbf{1 - 4}$. Cocconeis costata Gregory: $(1,2)$ Sample 317-U1352B-23H-4W, 110-111 cm; $(3,4)$ Sample 47X-3W, $97-98 \mathrm{~cm}$. 5-10. Cocconeis fasciolata (Ehrenberg) Brown: $(5,6)$ Sample 317-U1352B-47X-2W, 23-24 cm; $(7,8)$ Sample 22H1W, 117-118 cm; $(9,10)$ Sample 42X-3W, 105-106 cm. 11-20. Cocconeis aff. placentula Ehrenberg: $(11,12)$ Sample 317-U1352B-40X-4W, 105-106 cm; $(13,14)$ Sample 10H-3W, 100-101 cm; $(15,16)$ Sample 38X-6W, 25$26 \mathrm{~cm}$; $(17,18)$ Sample 22H-2W, 109-110 cm; $(19,20)$ Sample 55X-3W, 72-73 cm. 21-29. Cocconeis schuettii Van Heurck: (21) Sample 317-U1352B-25H-6W, 50-51 cm; $(22,23)$ Sample 62X-6W, 27-28 cm; (24, 25) Sample 40X-3W, 105-106 cm; $(26,27)$ Sample 42X-5W, 100-101 cm; $(28,29)$ Sample 61X-1W, 21-22 cm. 30, 31. Cocconeis sp. A of Harwood et al. (2000) (Sample 317-U1352B-33H-2W, 28-29 cm). 32-39. Cocconeis sp. B: (32, 33) Sample 317-U1352B-22H-5W, 39-40 cm; $(34,35)$ Sample 23H-4W, 110-111 cm; $(36,37)$ Sample 40X-1W, 105$106 \mathrm{~cm}$; $(38,39)$ Sample 21H-5W, 46-47 cm. 40-43. Cocconeis spp.: (40) Sample 317-U1352B-58X-8W, 25-26 cm; (41, 42) Sample 59X-2W, 121-122 cm; (43) Sample 79X-1W, 38-39 cm. 44, 45. Navicula directa (Smith) Ralfs in Pritchard (Sample 317-U1352B-39X-5W, 99-100 cm). 46, 47. Navicula wisei Harwood et Maruyama (Sample 317-U1352B-10H-4W, 100-101 cm). 48-51. Navicula spp.: $(48,49)$ Sample 317-U1352B-61X-2W, 23-24 cm; (50, 51) Sample 7H-1W, 110-111 cm. 52-57. Nitzschia panduriformis Gregory: (52, 53) Sample 317-U1352B-21H-2W, 35-36 cm; $(54,55)$ Sample 17H-2W, 114-115 cm; $(56,57)$ Sample 55X-3W, 72-73 cm. 58-63. Rhaphoneis amphiceros (Ehrenberg) Ehrenberg: $(58,59)$ Sample 317-U1352B-50X-2W, 33-34 cm; $(60,61)$ Sample 34H-5W, 34$35 \mathrm{~cm}$; $(62,63)$ Sample $34 \mathrm{H}-1 \mathrm{~W}, 4-5 \mathrm{~cm}$. (Plate shown on next page.) 
Plate P6 (continued). (Caption shown on previous page.)

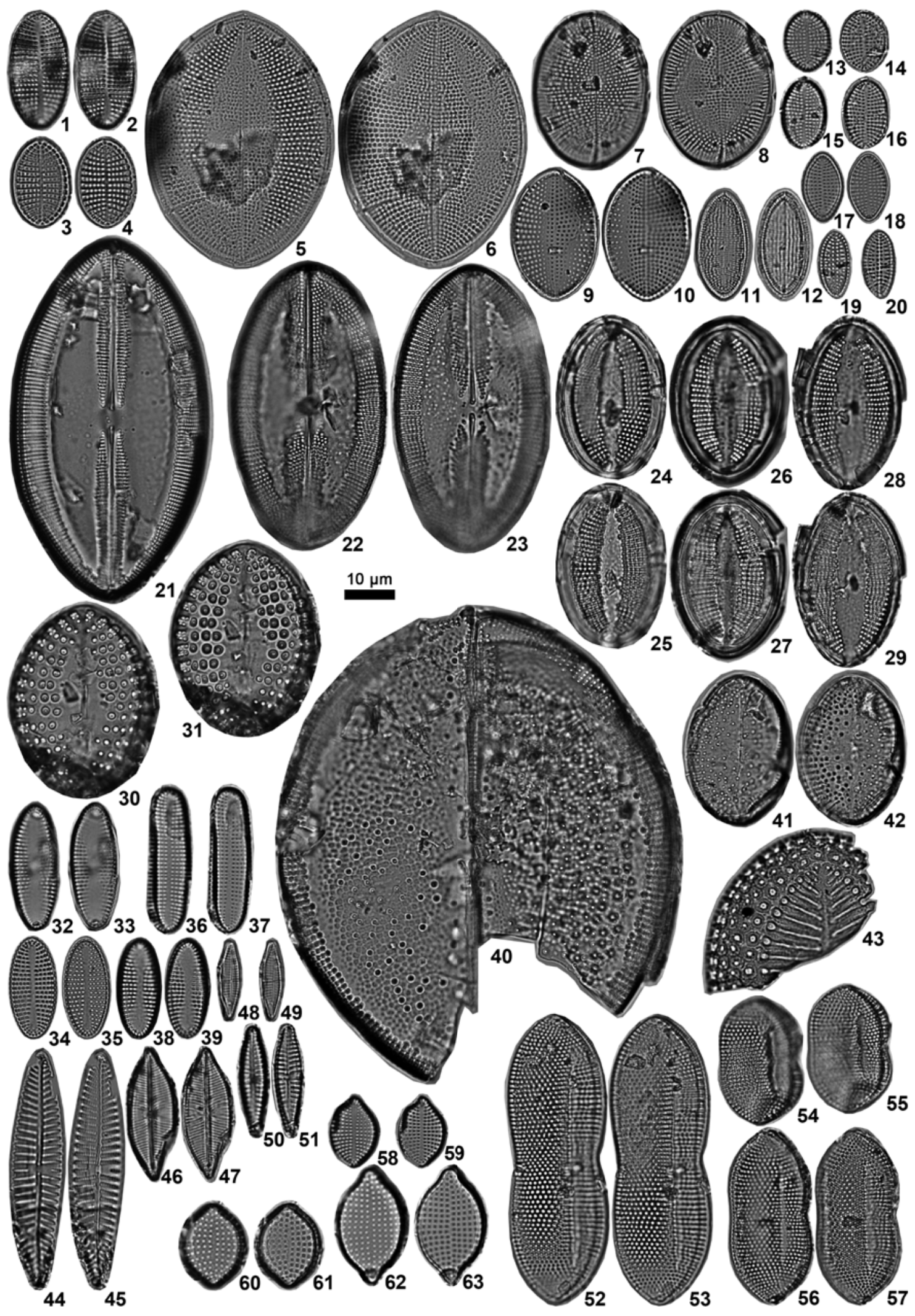


Plate P7. Light microscope images of littoral to neritic diatoms, Hole U1352B. Scale bars = $10 \mu \mathrm{m}$. 1-6. Diploneis bombus Ehrenberg: $(1,2)$ Sample 317-U1352B-67X-1W, 44-45 cm; $(3,4)$ Sample 66X-1W, 10-11 cm; $(5,6)$ Sample 22H-3W, 120-121 cm. 7-12. Diploneis frickei (Van Heurck) Heiden et Kolbe: $(7,8)$ Sample 317-U1352B-25H1W, 25-26 cm; $(9,10)$ Sample 33H-2W, 28-29 cm; $(11,12)$ Sample 28H-2W, 25-26 cm. 13-18. Diploneis splendida (Gregory) Cleve: $(13,14,17,18)$ Sample 317-U1352B-25H-1W, 25-26 cm; $(15,16)$ Sample 25H-5W, $25-26$ cm. 19-24. Diploneis subovalis Cleve: $(19,20)$ Sample 317-U1352B-14H-4W, 100-101 cm; $(21,22)$ Sample 32H2W, 80-81 cm; $(23,24)$ Sample 38X-2W, 99-100 cm. 25-28. Diploneis sp. (lanceolate): $(25,26)$ Sample 317U1352B-25H-2W, 25-26 cm; (27, 28) Sample 26H-5W, 100-101 cm. 29, 30. Diploneis sp. (Sample 317-U1352B25H-1W, 25-26 cm. 31-46. Grammatophora spp.: (31, 32) Sample 317-U1352B-59X-1W, 99-100 cm; $(33,34)$ Sample 38X-6W, 25-26 cm; (35, 36) Sample 52X-5W, 123-124 cm; $(37,38)$ Sample 13H-5W, 123-124 cm; $(39$, 40) Sample 40X-1W, 105-106 cm; $(41,42)$ Sample 23H-2W, 110-111 cm; $(43,44)$ Sample 61X-1W, 21-22 cm; $(45,46)$ Sample 56X-1W, 100-101 cm.

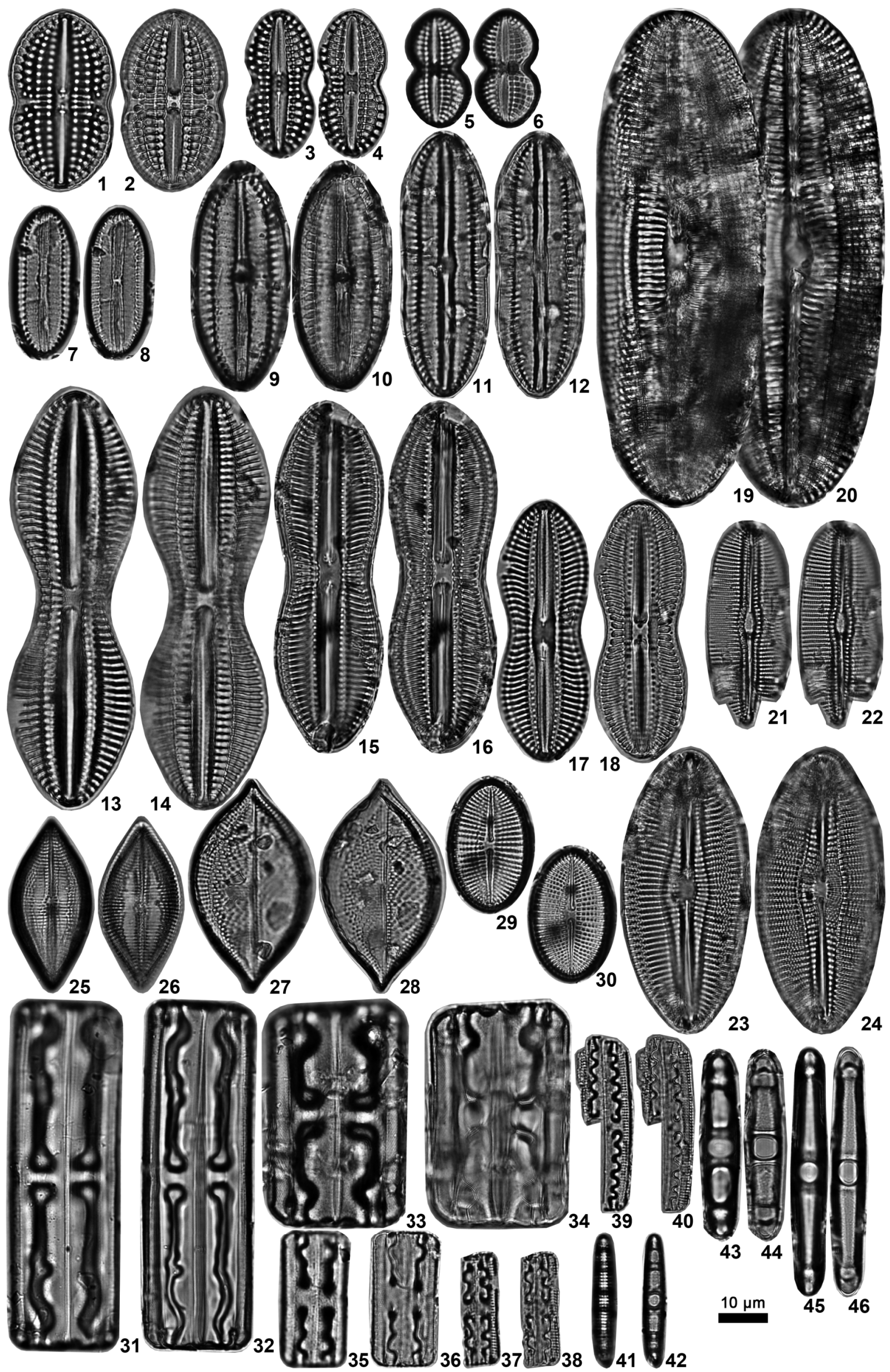


Plate P8. Light microscope images of littoral to neritic diatoms, Hole U1352B. Scale bars $=10 \mu \mathrm{m} .1$, 2. Pleurosigma directum Grunow in Cleve et Grunow (Sample 317-U1352B-26H-6W, 25-26 cm). 3-8. Rhaphoneis spp.: (36) Sample 317-U1352B-25H-1W, 25-26 cm; $(7,8)$ Sample 48X-3W, 79-80 cm. 9, 10. Rhopalodia sp. (Sample 317U1352B-47X-7W, 27-28 cm). 11-16. Stauroneis spp.: $(11,12)$ Sample 317-U1352B-42X-5W, 100-101 cm; $(13$, 14) Sample 61X-2W, 23-24 cm; $(15,16)$ Sample 27H-1W, 100-101 cm. 17-20. Trachyneis spp.: $(17,18)$ Sample 317-U1352B-33H-2W, 28-29 cm; (19, 20) Sample 23H-5W, 100-101 cm. 21-34. Stephanopyxis spp.: (21, 22) Sample 317-U1352B-22H-2W, 109-110 cm; $(23,24)$ Sample 19H-5W, 135-136 cm; $(25,26)$ Sample 38X-6W, 25$26 \mathrm{~cm}$; $(27,28)$ Sample 14H-5W, 90-91 cm; $(29,30)$ Sample 12H-5W, 128-129 cm; $(31,32)$ Sample 25H-3W, 25-26 cm; $(33,34)$ Sample 40X-4W, 105-106 cm. 35-48. Thalassionema nitzschioides (Grunow) Mereschkowsky: $(35,36)$ Sample 317-U1352B-7H-3W, 119-120 cm; $(37,38)$ Sample 42X-5W, 100-101 cm; $(39,40)$ Sample 25H4W, 25-26 cm; $(41,42)$ Sample 59X-1W, 99-100 cm; $(43,44)$ Sample 23H-1W, 25-26 cm; $(45,46)$ Sample 33H2W, 28-29 cm; $(47,48)$ Sample 34H-5W, 34-35 cm. (Plate shown on next page.) 
Plate P8 (continued). (Caption shown on previous page.)
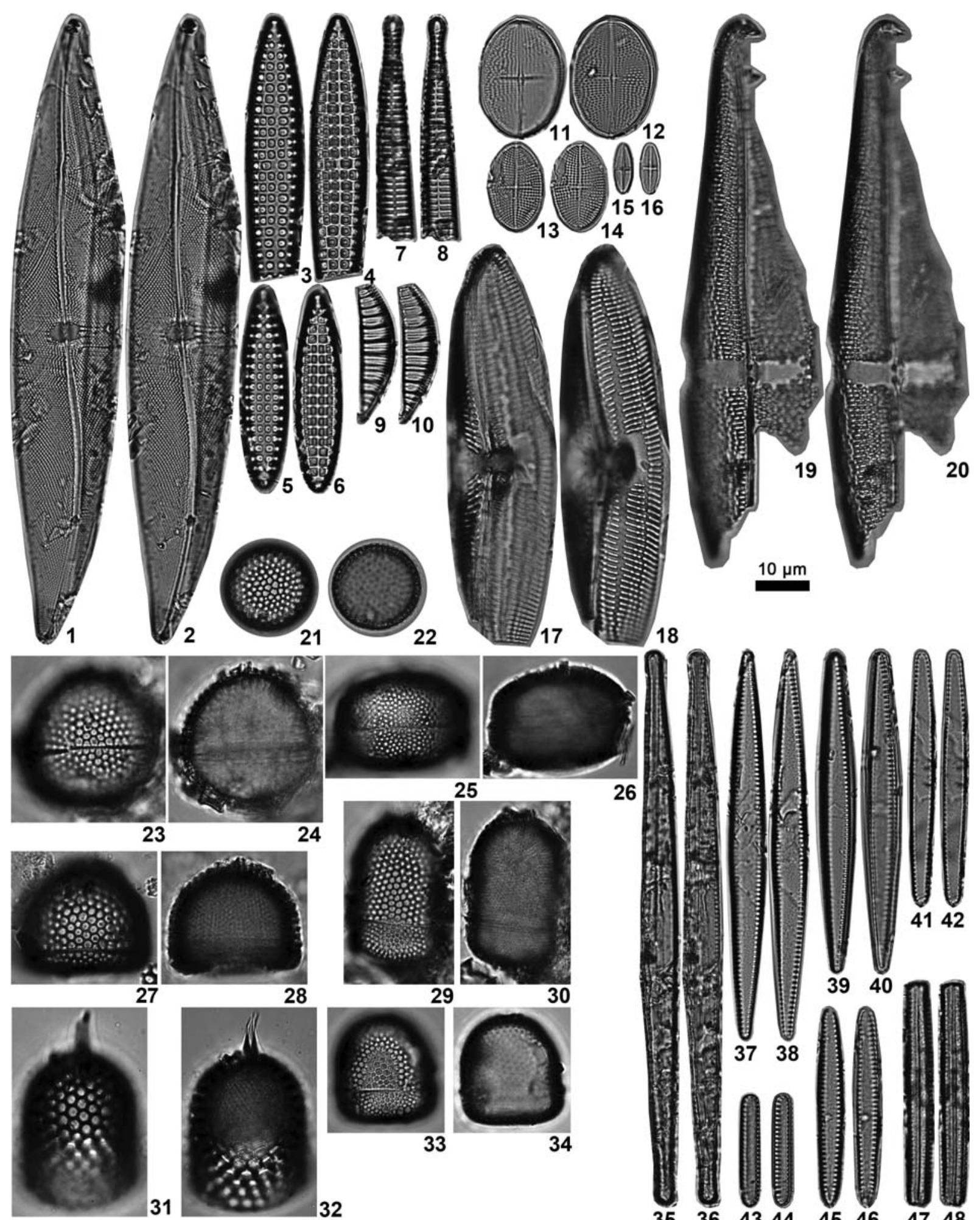

18

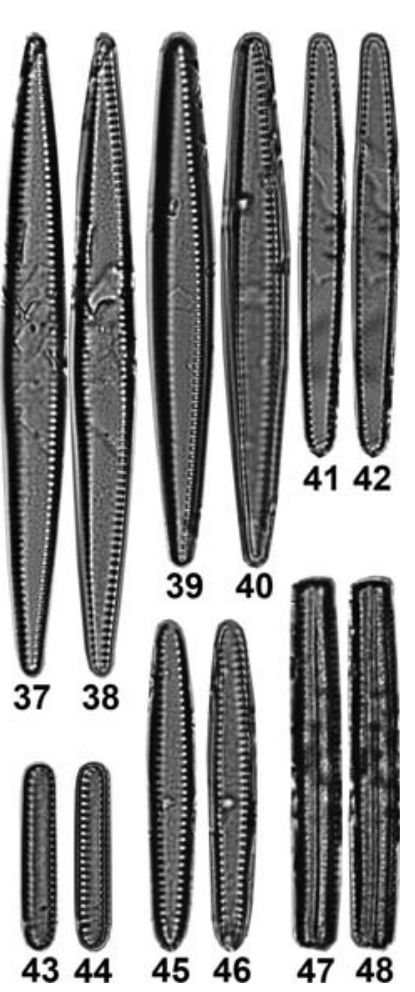


Plate P9. Light microscope images of freshwater diatoms (figures 1-56) and marine diatom genus Chaetoceros resting spores indicating upwelling and high-nutrient regions (figures 57-96), Hole U1352B. Scale bars $=10 \mu \mathrm{m}$. 1-8. Aulacoseira granulata (Ehrenberg) Simonsen: $(1,2)$ Sample 317-U1352B-5H-4W, 109-110 cm; $(3,4)$ Sample 31H-2W, 58-59 cm; (5, 6) Sample 5H-5W, 101-102 cm; (7, 8) Sample 3H-6W, 74-75 cm. 9-18. Cyclotella pantanelliana Castracane: $(9,10)$ Sample 317-U1352B-2H-2W, 138-139 cm; $(11,12)$ Sample 25H-1W, 25-26 cm; $(13-$ 16) Sample 19H-3W, 36-37 cm; $(17,18)$ Sample 5H-4W, 109-110 cm. 19-30. Cymbella spp.: $(19,20)$ Sample 317-U1352B-47X-5W, 24-25 cm; $(21,22)$ Sample 90X-1W, 31-32 cm; $(23,24)$ Sample 85X-1W, 44-45 cm; $(25$, 26) Sample 85X-2W, 25-26 cm; $(27,28)$ Sample 39X-5W, 99-100 cm; $(29,30)$ Sample 81X-4W, 25-26 cm. 3144. Discostella stelligera (Cleve et Grunow) Houk et Klee: $(31,32)$ Sample 317-U1352B-3H-6W, 74-75 cm; (33, 34) Sample 5H-3W, 9-10 cm; $(35,36)$ Sample 1H-6W, 10-11 cm; $(37-40,43,44)$ Sample 12H-7W, 36-37 cm; $(41,42)$ Sample 7H-2W, 60-61 cm. 45-48. Encyonema spp.: $(45,46)$ Sample 317-U1352B-26H-6W, 25-26 cm; $(47,48)$ Sample 26H-4W, 100-101 cm. 49-52. Epithemia spp.: $(49,50)$ Sample 317-U1352B-6H-1W, 112-113 cm; $(51,52)$ Sample 21H-3W, 27-28 cm. 53-56. Eunotia spp.: $(53,54)$ Sample 317-U1352B-41X-7W, 30-31 cm; $(55,56)$ Sample 42X-5W, 100-101 cm. 57-62. Xanthiopyxis type A (knobby type) of Suto $(2004 d):(57,58)$ Sample 317-U1352B-12H-5W, 128-129 cm; $(59,60)$ Sample 26H-2W, 100-101 cm; $(61,62)$ Sample 43X-5W, 105-106 cm. 63-78. Xanthiopyxis type B (short spiny type) of Suto (2004d): (63, 64) Sample 317-U1352B-12H5W, 128-129 cm; $(65,66)$ Sample 22H-3W, 120-121 cm; $(67,68)$ Sample 26H-2W, 100-101 cm; $(69$, 70) Sample 40X-3W, 105-106 cm; (71, 72) Sample 44X-1W, 105-106 cm; (73, 74) Sample 38X-2W, 99-100 cm; $(75,76)$ Sample 40X-2W, 25-26 cm; (77, 78) Sample 39X-1W, 24-25 cm. 79-84. Xanthiopyxis type C (long spiny type) of Suto (2004d): $(79,80)$ Sample 317-U1352B-26H-5W, 100-101 cm; $(81,82)$ Sample 38X-2W, 99-100 cm; (83, 84) Sample 41X-7W, 30-31 cm. 85-96. Hyaline type resting spores: $(85,86)$ hyaline type epivalve, Sample 317U1352B-23H-4W, 110-111 cm; (87, 88) hyaline type hypovalve, Sample 61X-2W, 23-24 cm; $(89,90)$ Sample 43X-6W, 24-25 cm; $(91,92)$ Sample 38X-2W, 99-100 cm; $(93,94)$ Sample 52X-5W, 123-124 cm; $(95,96)$ Sample 25H-6W, 50-51 cm. (Plate shown on next page.) 
Plate P9 (continued). (Caption shown on previous page.)

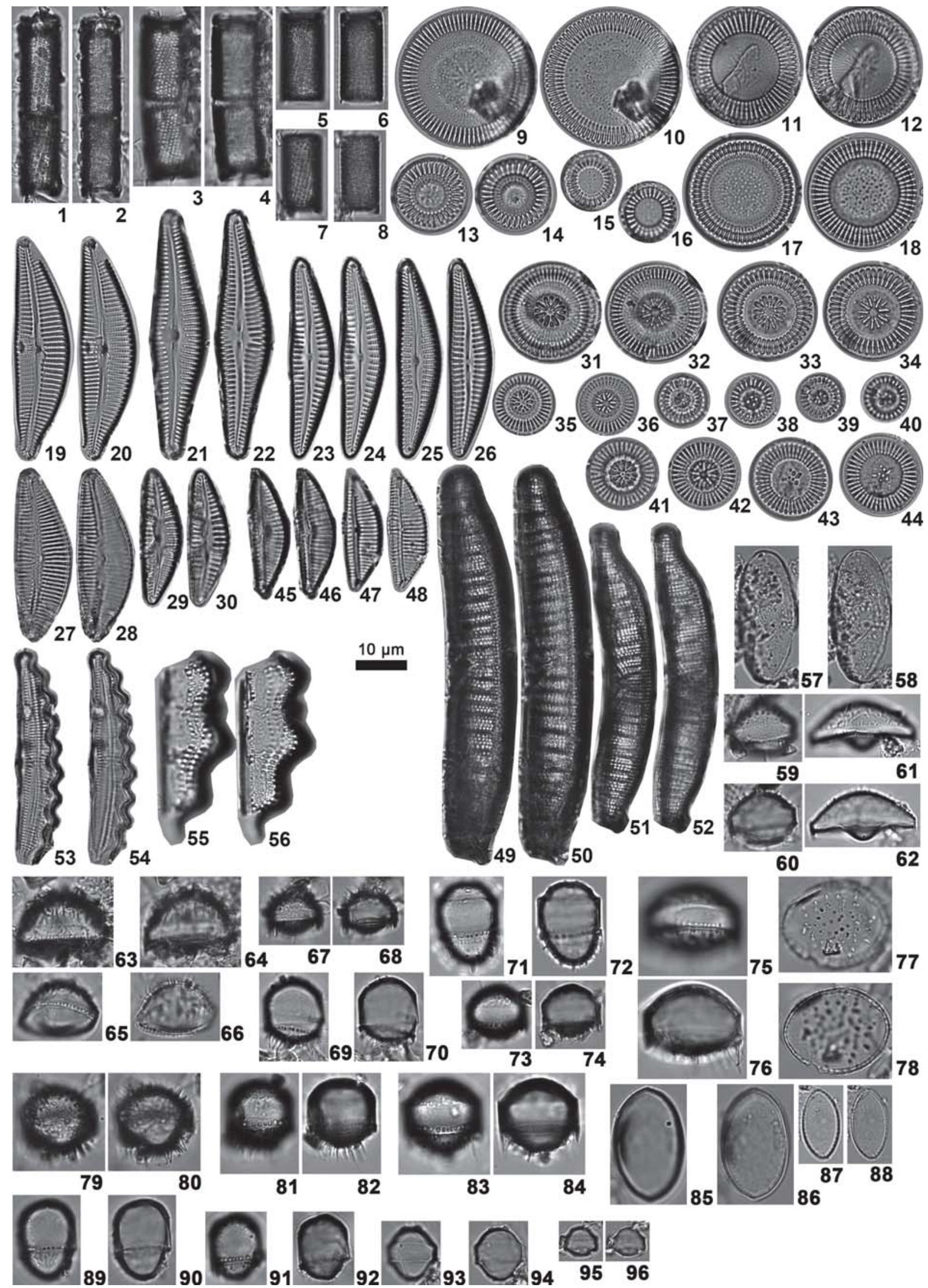


Plate P10. Light microscope images of marine diatom genus Chaetoceros resting spores indicating upwelling and high-nutrient regions, Hole U1352B. Scale bars $=10 \mu \mathrm{m} .1$, 2. Coronodiscus collarius Suto (Sample 317U1352B-12H-5W, 128-129 cm). 3-6. Dicladia capreola Ehrenberg: (3, 4) Sample 317-U1352B-27H-2W, 93-94 cm; (5, 6) Sample 27H-5W, 25-26 cm. 7-10. Dicladia ? spp. (Sample 317-U1352B-32H-3W, 80-81 cm). 11-16. Dispinodiscus pilusus var. montanus Suto: $(11,12)$ Sample 317-U1352B-22H-6W, $115-116 \mathrm{~cm} ;(13,14)$ Sample 27H-5W, 25-26 cm; $(15,16)$ Sample 56X-4W, 105-106 cm. 17, 18. Dispinodiscus pilusus var. pilusus Suto (Sample 317-U1352B-26H-5W, 100-101 cm). 19-24. Dispinodiscus stimulus Suto: (19, 20) Sample 317-U1352B19H-5W, 135-136 cm; $(21,22)$ Sample 38X-2W, 99-100 cm; $(23,24)$ Sample 34H-5W, 34-35 cm. 25-34. Gemellodiscus bifurcus Suto: $(25,26)$ Sample 317-U1352B-52X-5W, 123-124 cm; $(27,28)$ Sample 34H-5W, 34-35 cm; (29-32) Sample 27H-5W, 25-26 cm; (33, 34) Sample 26H-2W, 100-101 cm. 35, 36. Gemellodiscus cingulus (Sample 317-U1352B-25H-5W, 25-26 cm). 37, 38. Hypovalve of Gemellodiscus (Sample 317-U1352B-39X-5W, 99-100 cm). 39-46. Liradiscus castaneus var. castaneus Suto: $(39,40)$ Sample 317-U1352B-25H-4W, 25-26 cm; $(41,42)$ Sample 38X-1W, 25-26 cm; $(43,44)$ Sample 39X-3W, 25-26 cm; $(45,46)$ Sample 58X-7W, 80-81 cm. 47, 48. Liradiscus japonicus Suto (Sample 317-U1352B-25H-3W, 25-26 cm). 49, 50. Liradiscus pacificus Suto (Sample 317-U1352B-35H-1W, 32-33 cm). 51-54. Liradiscus plicatulus Hajós: (51, 52) Sample 317-U1352B-7H2W, 93-94 cm; (53, 54) Sample 56X-4W, 105-106 cm. 55, 56. Monocladia sp. (Sample 317-U1352B-27H-5W, 25$26 \mathrm{~cm}) .57-62$. Quadrocistella rectagonuma Suto: $(57,58)$ Sample 317-U1352B-22H-3W, $120-121 \mathrm{~cm} ;(59,60)$ Sample 23H-1W, 25-26 cm; (61, 62) Sample 12H-5W, 128-129 cm. 63-74. Syndendrium diadema Ehrenberg: (63, 64) Sample 317-U1352B-26H-3W, 94-95 cm; (65-68, 71, 72) Sample 43X-5W, 105-106 cm; (69, 70) Sample 43X-6W, 24-25 cm; $(73,74)$ Sample 40X-1W, 105-106 cm. 75-78. Vallodiscus complexus Suto: $(75,76)$ Sample 317-U1352B-16H-7W, 24-25 cm; $(77,78)$ Sample 17H-1W, 115-116 cm. 79-84. Xanthiopyxis hirsuta Hanna et Grant: (79, 80) Sample 317-U1352B-22H-1W, 117-118 cm; $(81,82)$ Sample 24H-6W, 110-111 cm; $(83,84)$ Sample 56X-4W, 105-106 cm. 85, 86. Xanthiopyxis polaris Gran (Sample 317-U1352B-55X-3W, 72-73 cm). (Plate shown on next page.) 
Plate P10 (continued). (Caption shown on previous page.)

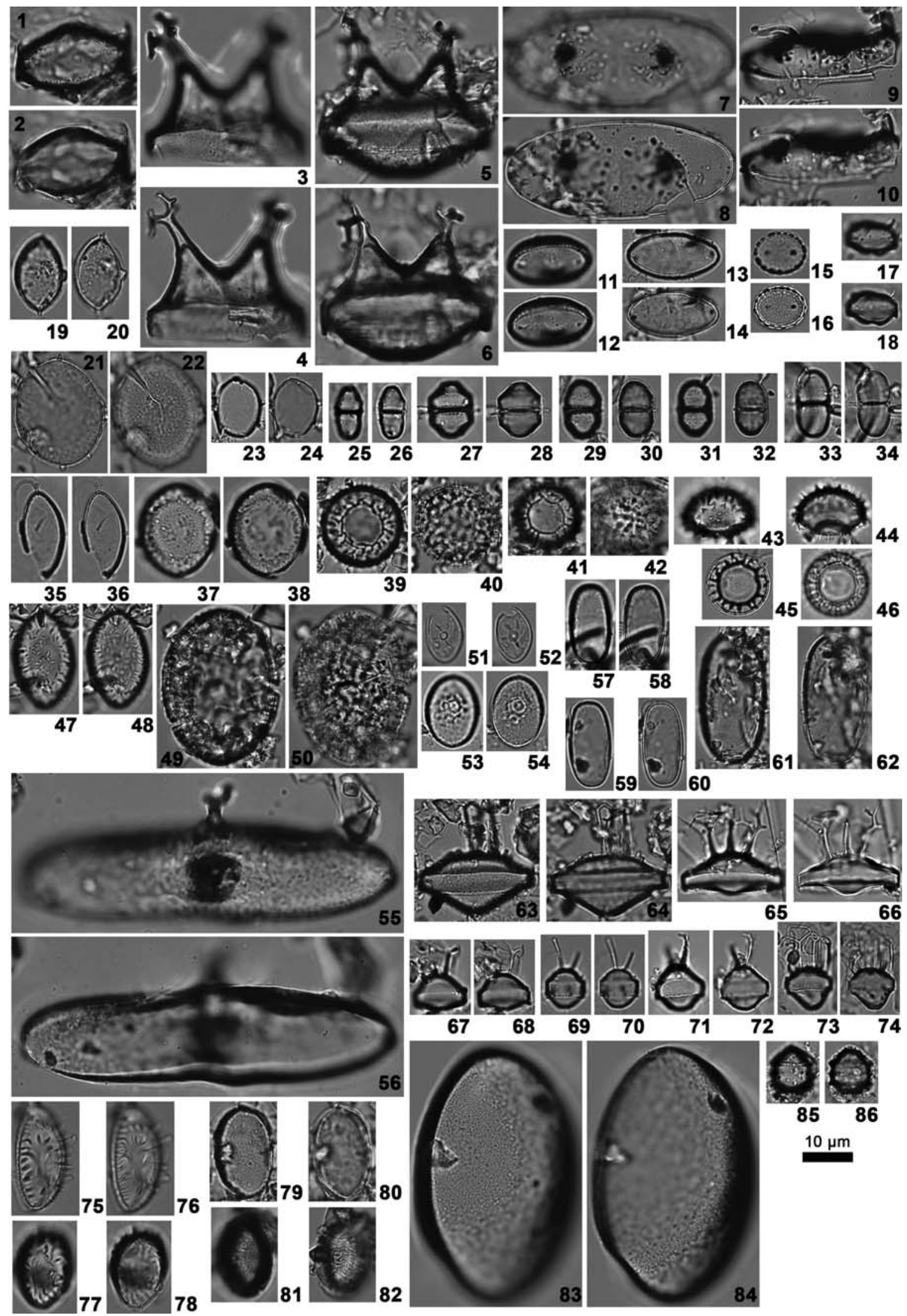


Plate P11. Scanning electron microscope images of diatoms (Sample 317-U1352B-27H-6W, 25-26 cm). Scale bars $=10 \mu \mathrm{m}$. 1. Fragilariopsis kerguelensis (O'Meara) Hustedt. 2. Fragilariopsis obliquecostata (Van Heurck) Heiden et Kolbe. 3. Thalassiosira sp. d of Fenner et al. (1976). 4. Cocconeis sp. B. 5, 6. Nitzschia panduriformis Gregory. 7, 8. Cocconeis aff. placentula Ehrenberg.
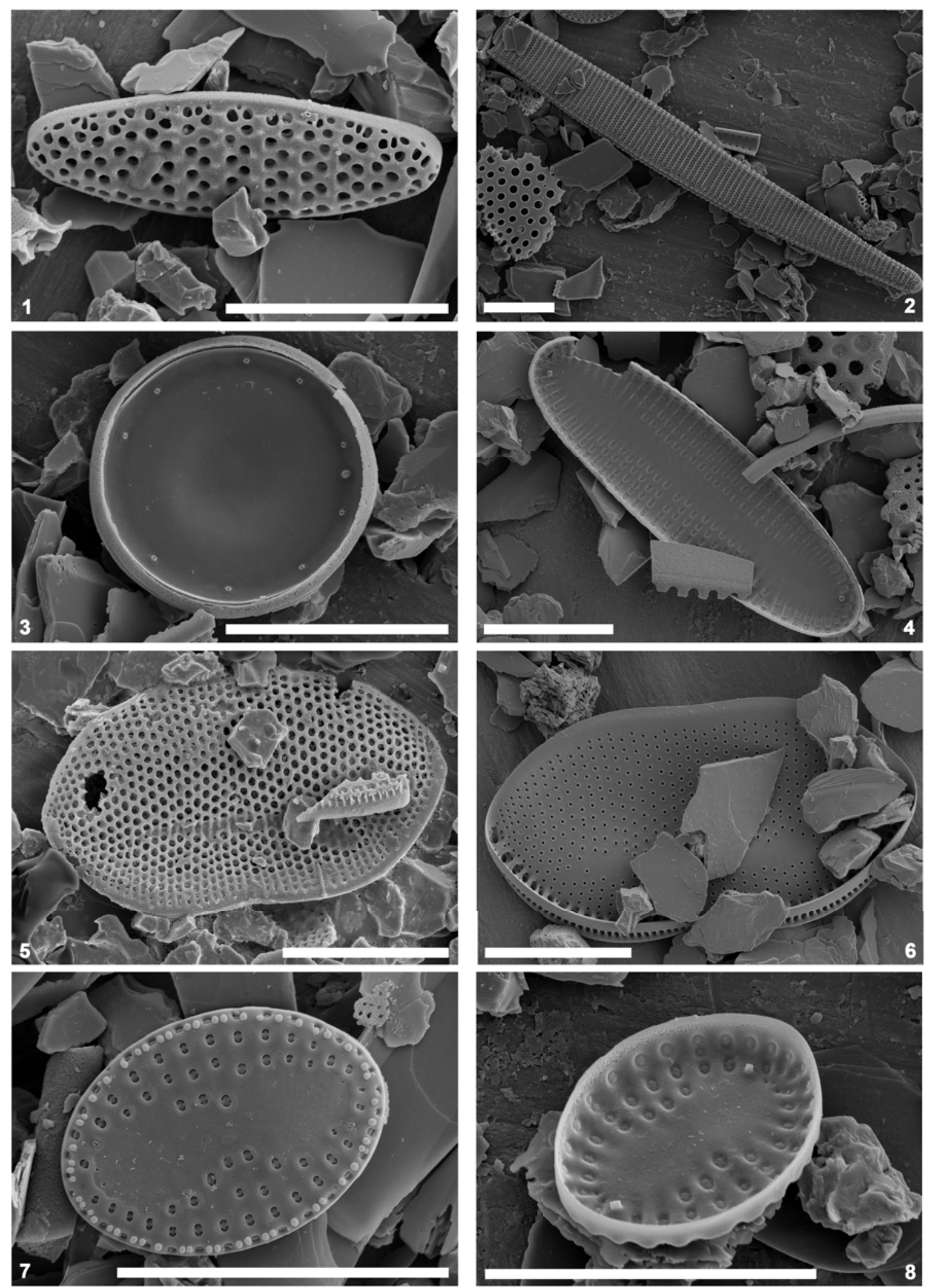
Plate P12. Scanning electron microscope images of Chaetoceros resting spores (Sample 317-U1352B-27H-6W, $25-26 \mathrm{~cm}$ ). Scale bars $=10 \mu \mathrm{m}$. 1. Coronodiscus collarius Suto. 2. Dispinodiscus pilusus var. montanus Suto. 3. Gemellodiscus bifurcus Suto. 4. Liradiscus castaneus var. castaneus Suto. 5. Liradiscus plicatulus Hajós. 6. Quadrocistella rectagonuma Suto. 7. Xanthiopyxis type A (knobby type) of Suto (2004d). 8. Xanthiopyxis type B (short spiny type) of Suto (2004d).
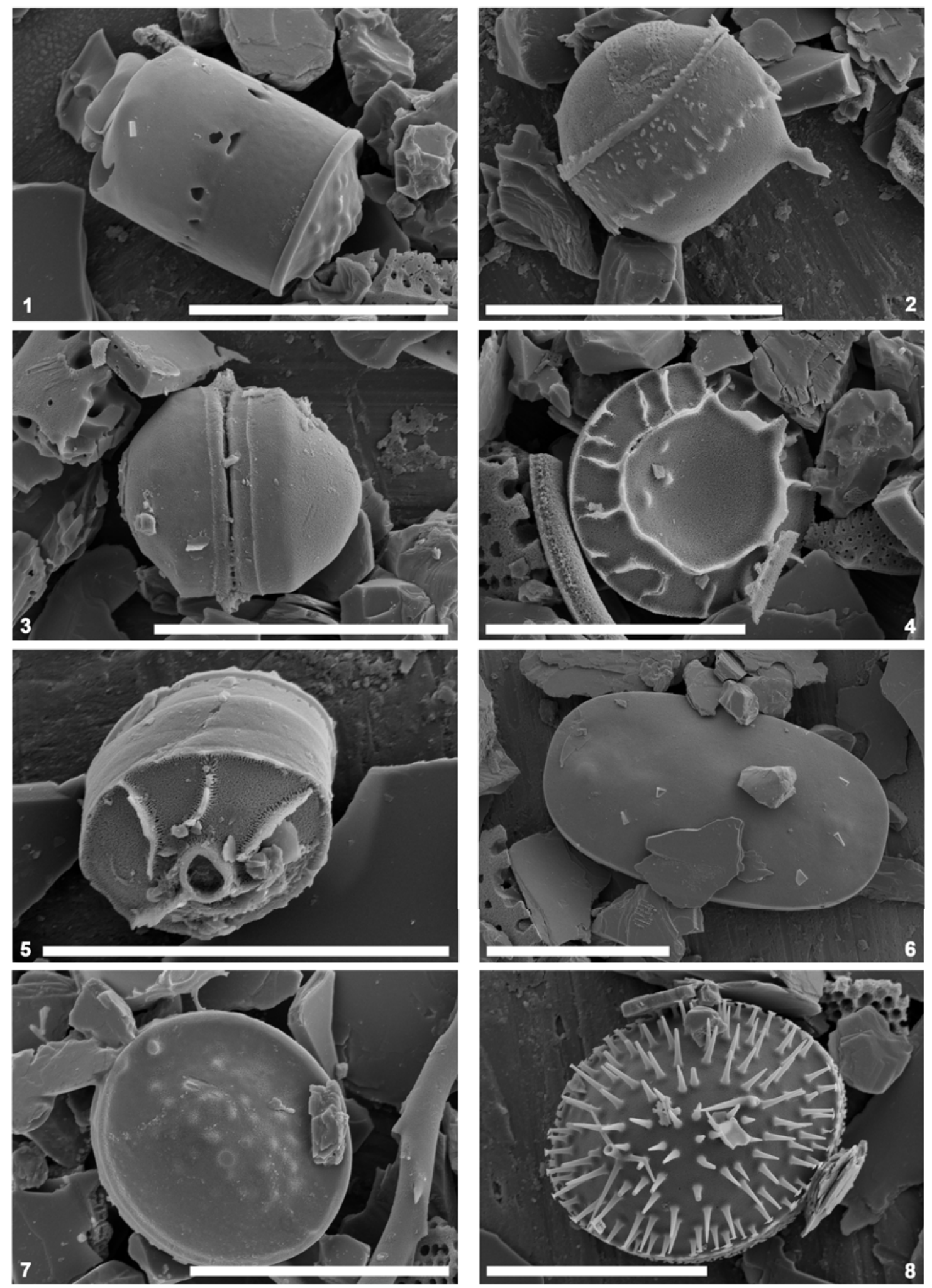


\section{Appendix}

\section{Taxonomic notes and floral references}

Taxonomic references for all species and varieties of diatoms (Bacillariophyta) identified from the Expedition 317 Hole U1352B sediments are listed below. The authority of each species is given as well as several good references that describe and illustrate the particular taxon collected around the Antarctic Ocean. Plates P1-P4, P5-P8, and P9 (figs. 1-56) show diatoms living in marine, littoral to neritic, and freshwater (nonmarine), respectively, with SEM photos in Plate P11, in addition to morphotaxa of marine diatom genus Chaetoceros resting spores represented in Plates P9, P10, and P12.

\section{Marine}

Actinocyclus actinochilus (Ehrenberg) Simonsen (1982), pp. 101-116, pls. 1-4; Harwood and Maruyama (1992), p. 699, pl. 12, figs. 9-11; Iwai and Winter (2002), p. 3, pl. P21, fig. 8; pl. P26, fig. 2; pl. P33, fig. 1 (Pl. P1, figs. 1 , 2).

Basionym: Coscinodiscus actinochilus Ehrenberg (1844a), p. 200; Ehrenberg (1854), pl. 35A, figs. XXI-5.

Synonym: Charcotia actinochilus (Ehrenberg) Hustedt (1958), pp. 122-126, pl. 7, figs. 57-80; Fenner et al. (1976), p. 771, pl. 5, fig. 5; Gombos (1977), p. 592, pl. 1, fig. 8.

Remarks: Gombos (1977) reported that this taxon is indicative of extreme polar (ice-front) conditions.

Actinocyclus curvatulus Janisch in Schmidt (1878), pl. 57, fig. 31; Fenner et al. (1976), p. 763, pl. 6, figs. 1, 2; Harwood and Maruyama (1992), p. 699, pl. 12, fig. 12; Zielinski and Gersonde (2002), p. 253, pl. 3, fig. 1 (Pl. P1, figs. 3-14).

Remarks: Fenner et al. (1976) indicated that this species is frequent in the Antarctic and subantarctic regions.

Actinocyclus cf. fasciculatus (no illustrations).

Actinocyclus ingens Rattray (1890), p. 149, pl. 11, fig. 7; Harwood and Maruyama (1992), p. 700, pl. 8, fig. 10; pl. 11, figs. 4, 6; pl. 12, fig. 8; Iwai and Winter (2002), p. 3, pl. P15, fig. 3; pl. P29, figs. 1, 4 (Pl. P1, figs. 15, 16).

Actinocyclus sp. A (P1. P1, figs. 17-22).

Actinocyclus sp. B (P1. P1, figs. 23, 24).

Actinocyclus spp. (no illustrations).

Actinoptychus bipunctatus Lohman (1941), p. 79, pl. 16, figs. 7, 10-12; Arney et al. (2003), p. 8, pl. P1, fig. 4 (P1. P1, figs. 25-28).

Actinoptychus spp. (P1. P1, figs. 29-34).

Asteromphalus hyalinus Karsten (1905), p. 90, pl. 8, fig. 15; Schrader (1976), p. 630, pl. 8, figs. 5, 7; Fenner et al. (1976), p. 769, pl. 4, figs. 17-19 (Pl. P1, figs. 35, 36).

Remarks: Hustedt (1958) and Hargraves (1968) reported this species from the Antarctic and subantarctic regions in the southern Atlantic.
Cestodiscus cf. pulchellus Greville (1866), p. 123, pl. 11, fig. 5; Harwood and Maruyama (1992), p. 701, pl. 3, figs. 6, 7 (no illustrations).

Coscinodiscus asteromphalus Ehrenberg (1844b), p. 77; Arney et al. (2003), p. 8, pl. P3, fig. 3 (Pl. P2, figs. 1, 2).

Coscinodiscus marginatus Ehrenberg (1843), p. 412 (124); McCollum (1975), p. 527, pl. 16, figs. 2, 3; Schrader (1976), p. 631, pl. 10, fig. 3; pl. 12, fig. 2; Gombos (1977), p. 593, pl. 5, fig. 5; Iwai and Winter (2002), p. 5, pl. P30, fig. 2; pl. P31, fig. 5; Arney et al. (2003), p. 8, pl. P1, fig. 1 (P1. P2, figs. 3, 4).

Coscinodiscus radiatus Ehrenberg (1840b), p. 68 (148), pl. 3, figs. 1a-1c; Fenner et al. (1976), p. 774, pl. 7, fig. 1; Iwai and Winter (2002), p. 5, pl. P22, fig. 1 (P1. P2, figs. 5, 6).

Coscinodiscus spp. (P1. P2, figs. 7, 8).

Eucampia antarctica (Castracane) Manguin (1915), p. 58, figs. 41, 42, pl. 1, fig. 1; Hasle and Syvertsen (1990), pl. 16.1, figs. 7-13; Harwood et al. (2000), p. 459, figs. 7r, 7s; Iwai and Winter (2002), p. 6, pl. P7, fig. 12; pl. P27, fig. 6 (P1. P1, figs. 37, 38).

Synonym: Eucampia balaustium Castracane (1886a), p. 97, pl. 18, fig. 5; McCollum (1975), p. 534, pl. 16, figs. 8, 9; Schrader (1976), p. 632, pl. 14, fig. 7; Fenner et al. (1976), p. 774, pl. 5, figs. 7-9; Gombos (1977), p. 593, pl. 1, figs. 1, 2, pl. 11 .

Fragilariopsis barronii (Gersonde) Gersonde et Bárcena (1998), p. 92; Harwood et al. (2000), p. 459, fig. 10m; Iwai and Winter (2002), p. 7, pl. P25, fig. 3; Zielinski and Gersonde (2002), p. 257, pl. 1, figs. 29-31 (Pl. P3, figs. 1-4).

Basionym: Nitzschia barronii Gersonde (1991), pp. 146147, pl. 3, fig. 6; pl. 4, figs. 1-3; pl. 5, figs. 7-17; Gersonde and Burckle (1990), p. 780, pl. 1, figs. 11-13; Baldauf and Barron (1991), p. 589, pl. 7, fig. 14; Harwood and Maruyama (1992), p. 704, pl. 17, figs. 27, 28.

Remarks: This extinct species is endemic to the Southern Ocean (Gersonde, 1991).

Fragilariopsis barronii/kerguelensis transitional form of Zielinski and Gersonde (2002), p. 257, pl. 1, figs. 25-28 (Pl. P3, figs. 5-10).

Fragilariopsis cylindrica (Burckle) Censarek et Gersonde (2002), pp. 349-350, pl. 3, fig. 24 (Pl. P3, figs. 11-16).

Basionym: Nitzschia cylindrica Burckle (1972), p. 239, pl. 2, figs. 1-6; Gersonde and Burckle (1990), p. 780, pl. 1, fig. 27; Baldauf and Barron (1991), p. 589, pl. 7, fig. 10; Iwai and Winter (2002), p. 8, pl. P2, figs. 5, 6.

Remarks: Fragilariopsis cylindrica seems to be an indicator of warm waters because Barron (1985) indicated that this species is a low-latitude species and is rare in middlelatitude sediments.

Fragilariopsis doliolus (Wallich) Medlin et Sims (1993), p. 332; Zielinski and Gersonde (2002), p. 257, pl. 1, fig. 1 (Pl. P3, figs. 17, 18).

Basionym: Synedra doliolus Wallich (1860), p. 48, pl. 2, fig. 19 . 
Synonym: Pseudoeunotia doliolus (Wallich) Grunow in Van Heurck (1881), pl. 35, fig. 22; Fenner et al. (1976), p. 778, pl. 14, fig. 12 .

Remarks: This species is one of the most common planktonic species in subtropical to tropical areas (Fenner et al., 1976).

Fragilariopsis fossilis (Frenguelli) Medlin et Sims (1993), p. 332; Censarek and Gersonde (2002), p. 351, pl. 3, figs. 3, 4; Zielinski and Gersonde (2002), p. 257, pl. 1, figs. 5, 6 (Pl. P3, figs. 19-22).

Basionym: Pseudonitzschia fossilis Frenguelli (1949), p. 118, pl. 1, figs. $6,7$.

Synonym: Nitzschia fossilis (Grunow) Grunow in Van Heurck (1881), pl. 68, fig. 24; Gombos (1977), p. 595, pl. 8, fig. 17; Gersonde and Burckle (1990), p. 780, pl. 1, figs. 19, 20.

Remarks: This species is a low- to middle-latitude species (Barron, 1985).

Fragilariopsis kerguelensis (O'Meara) Hustedt (1952), p. 294; Iwai and Winter (2002), p. 7, pl. P3, figs. 1-3; pl. P24, fig. 3; pl. P25, fig. 1; Zielinski and Gersonde (2002), p. 259, pl. 1, fig. 24; Arney et al. (2003), p. 9, pl. P1, fig. 14; Bohaty et al. (2003), p. 22, pl. P2, fig. 13 (Pl. P3, figs. 23-38; P1. P11, fig. 1).

Basionym: Terebraria kerguelensis O'Meara (1877), p. 56, pl. 1, fig. 4 .

Synonym: Nitzschia kerguelensis (O'Meara) Hasle (1972), p. 115, figs. 1, 2; Fenner et al. (1976), p. 776, pl. 2, figs. 1930; Gombos (1977), p. 595, pl. 8, figs. 13, 14; pl. 9, fig. 2.

Remarks: This species is one of the most abundant forms in Antarctic and subantarctic regions (Fenner et al., 1976) and is endemic to the Southern Ocean (Barron, 1985).

Fragilariopsis obliquecostata (Van Heurck) Heiden in Heiden et Kolbe (1928), p. 555; Harwood et al. (2000), p. 459, fig. 10n (Pl. P11, fig. 2).

Basionym: Fragilaria obliquecostata Van Heurck (1909), p. 25, pl. 3, fig. 38 .

Synonym: Nitzschia obliquecostata (Van Heurck) Hasle (1972), p. 115; Fenner et al. (1976), pp. 776-777, pl. 2, figs. 15-18.

Remarks: This species is restricted to the Antarctic coastline and to the ice frontier (Fenner et al., 1976).

Fragilariopsis rhombica (O'Meara) Hustedt (1952), p. 296 (P1. P3, figs. 39, 40).

Basionym: Diatoma rhombicum O'Meara (1877), p. 55, pl. 1, fig. 2 .

Synonym: Nitzschia angulata Hasle (1972), p. 115; Fenner et al. (1976), p. 775, pl. 1, figs. 17-39; Gombos (1977), pl. 8, fig. 16; Ciesielski (1986), p. 876, pl. 3, fig. 13; Iwai and Winter (2002), p. 8, pl. P3, fig. 6.

Remarks: This species is reported from Antarctic circumpolar waters and the undersurface of ice-pack by several authors (Fenner et al., 1976).

Fragilariopsis weaveri (Ciesielski) Gersonde et Bárcena (1998), p. 93; Iwai and Winter (2002), p. 8, pl. P3, figs. 18-20; Zielinski and Gersonde (2002), p. 260, pl. 1, figs. 18, 19 (no illustrations).
Basionym: Nitzschia weaveri Ciesielski (1983), p. 655, pl. 1, figs. 1-10; Ciesielski (1986), p. 877, pl. 3, figs. 8-12; Baldauf and Barron (1991), p. 590, pl. 7, fig. 5.

Remarks: Barron (1996) used this species as a proxy of southward migration of the Polar Front.

Hemidiscus cuneiformis Wallich (1860), p. 42, pl. 2, figs. 3, 4; Fenner et al. (1976), p. 774, pl. 11, fig. 17; Harwood and Maruyama (1992), p. 703, pl. 11, fig. 11; Censarek and Gersonde (2002), p. 352, pl. 4, fig. 5; Iwai and Winter (2002), p. 8, pl. P21, fig. 2; Zielinski and Gersonde (2002), p. 260, pl. 4, fig. 10 (Pl. P2, figs. 9, 10).

Remarks: Tropical species (Koizumi et al., 2004).

Hemidiscus karstenii Jousé in Jousé et al. (1962), p. 78, pl. 2, figs. 7-9; McCollum (1975), p. 535, pl. 9, figs. 3, 4; Schrader (1976), p. 632, pl. 14, fig. 2; pl. 15, figs. 17, 18; Gombos (1977), p. 595, pl. 4, fig. 8; Ciesielski (1983), p. 656, pl. 3, fig. 6; pl. 4, figs. 2-5; Censarek and Gersonde (2002), p. 352, pl. 3, fig. 27; Iwai and Winter (2002), p. 8, pl. P21, fig. 5 (P1. P2, figs. 11-14).

Hemidiscus sp. 1 sensu Zielinski and Gersonde (2002), p. 260, pl. 4, fig. 8 (Pl. P2, figs. 15-18).

Nitzschia bicapitata Cleve (1900), p. 933, fig. 12; Fenner et al. (1976), p. 775, pl. 3, figs. 27-29 (Pl. P3, figs. 41, 42).

Remarks: This species has been reported from several subantarctic and Antarctic regions as well as in the Antarctic Convergence Zone with a maximum abundance (Fenner et al., 1976), although Koizumi et al. (2004) indicated this species is cosmopolitan.

Nitzschia denticuloides Schrader (1976), p. 633, pl. 3, figs. 7, 8, 10, 12, 18-24; pl. 15, fig. 22; Gombos (1977), p. 595, pl. 13, figs. 9-11; Ciesielski (1986), p. 876, pl. 3, fig. 18; Gersonde and Burckle (1990), p. 780, pl. 2, figs. 7, 8; Baldauf and Barron (1991), p. 589, pl. 7, fig. 2; Harwood and Maruyama (1992), p. 704, pl. 8, figs. 5-8, 17; pl. 9, figs. 24-26; pl. 10, fig. 1; Censarek and Gersonde (2002), p. 352 , pl. 2, figs. 27-31 (no illustrations).

Nitzschia spp. (P1. P3, figs. 43-48).

Pinnularia spp. (Pl. P3, figs. 49, 50).

Proboscia alata (Brightwell) Sundström (1986), pp. 99-100, figs. 258-266; Iwai and Winter (2002), p. 9, pl. P5, fig. 21 (P1. P3, figs. 51, 52).

Basionym: Rhizosolenia alata Brightwell (1858), p. 95, pl. 5, figs. 8, 8a; Fenner et al. (1976), p. 778, pl. 13, fig. 1; Harwood and Maruyama (1992), pl. 18, figs. 15, 17.

Remarks: Fenner et al. (1976) reported that this cosmopolitan species is found in Antarctic and subantarctic waters in the Antarctic Convergence Zone, and Jordan et al. (1991) indicated that this taxon, found in boreal waters, has been reported regularly from the Antarctic.

Proboscia barboi (Brun) Jordan et Priddle (1991), p. 56, figs. 1, 2; Harwood et al. (2000), p. 460, fig. 8d; Iwai and Winter (2002), p. 9 (Pl. P3, figs. 53, 54).

Basionym: Pyxilla barboi Brun (1894), p. 87, pl. 5, figs. 16, 17, 23; Rhizosolenia barboi (Brun) Tempère and Peragallo (1908), p. 26, no. 47; McCollum (1975), p. 535, pl. 11, fig. 13; Schrader (1976), p. 635, pl. 9, figs. 11-13; Ciesi- 
elski (1986), p. 877, pl. 3, fig. 22; Simonseniella barboi (Brun) Fenner (1991b), p. 108, pl. 3, figs. 1, 3; Harwood and Maruyama (1992), p. 706, pl. 11, fig. 13.

Remarks: Widely distributed species in the Antarctic Ocean (Jordan et al., 1991).

Proboscia curvirostris (Jousé) Jordan et Priddle (1991), p. 57, figs. 5-7 (P1. P3, figs. 55, 56).

Basionym: Rhizosolenia curvirostris Jousé (1959), p. 48, pl. 2, fig. 17; Jousé (1968), p. 19, pl. 3, figs. 1-3.

Remarks: This extinct species in the latest middle Pleistocene (at 0.3 Ma defined by Yanagisawa and Akiba, 1998) frequently occurred in sediments in the subarctic and North Pacific (e.g., Koizumi, 2010), although this taxon has been rarely reported around the Antarctic Ocean; the occurrence was recognized in Sample 317-U1352B-40X$5 \mathrm{~W}, 25-26 \mathrm{~cm}$, in this study.

Pseudodimerogramma sp. (P1. P3, figs. 57, 58).

Pseudonitzschia turgidula (Hustedt) Hasle (1993), p. 320 (Pl. P3, figs. 59, 60).

Basionym: Nitzschia turgidula Hustedt (1958), p. 182, figs. 172, 173; Fenner et al. (1976), p. 778, pl. 4, fig. 4 .

Remarks: This species was reported from Southern Ocean and South Atlantic (Hustedt, 1958).

Pseudonitzschia spp. (no illustrations).

Pterotheca aculeifera Grunow in Van Heurck (1880-1885), pl. 83 bis, fig. 5 (Pl. P3, figs. 61, 62).

Remarks: This taxon is mentioned as resting spore but does not belong to genus Chaetoceros because there is no ring of puncta at the hypovalve margin (Suto, 2003). The oldest and last occurrences of this cosmopolitan species are from the Late Cretaceous and the early Oligocene (see Suto et al., 2009). Desikachary and Sreelatha (1989) reported this species from the Eocene Oamaru Formation, New Zealand. Only one occurrence, recognized in Sample 317U1352B-45X-4W, 105-106 cm, might be reworked.

Rhizosolenia hebetata Bailey (1856), p. 5, pl. 1, figs. 18, 19

(P1. P3, figs. 63-68).

Remarks: Several forms of Rhizosolenia hebetata have been established such as forma hiemalis from the Antarctic and subantarctic regions (e.g., Schrader, 1976; Fenner et al., 1976; Baldauf and Barron, 1991; Harwood and Maruyama, 1992; Iwai and Winter, 2002). Armand and Zielinski (2001) indicated that the distribution pattern of the Rhizosolenia group in Antarctic surface waters is unclear as a result of taxonomic confusion.

Rhizosolenia polydactyla Castracane (1886a), p. 71, pl. 24, fig. 2 (Pl. P3, figs. 69-74).

Remarks: Confusion regarding identification has been seen in most Antarctic records of Rhizosolenia styliformis, such as Schrader (1976), Fenner et al. (1976), Harwood and Maruyama (1992), and Iwai and Winter (2002). However, $R$. polydactyla is distinguishable from $R$. styliformis by its lateral winglike expansions above the spiny process base. Armand and Zielinski (2001) suggested this is the most common open-ocean species of this genus based on their sediment distribution observation, and Hasle and Syvert- sen (1996) indicated this species is from southern cold-water regions.

Rouxia spp. (no illustrations).

Thalassiosira decipiens (Grunow) Jørgensen (1905), p. 96, pl. 6, fig. 3; Fenner et al. (1976), p. 779, pl. 11, figs. 4-6 (no illustrations).

Basionym: Coscinodiscus decipiens Grunow (1878), p. 125, pl. 4, fig. 18 .

Remarks: This species has a wide distribution in temperate and boreal waters in both hemispheres (Hasle, 1960).

Thalassiosira delicatula Hustedt (1958), p. 110, figs. 8-10; Fenner et al. (1976), p. 779, pl. 9, figs. 21-25 (P1. P2, figs. 19, 20).

Remarks: This is a widespread species in the Antarctic and subantarctic regions (Hargraves, 1968).

Thalassiosira eccentrica (Ehrenberg) Cleve emend. Fryxell et Hasle (1972), p. 302, figs. 1-18 (Pl. P2, figs. 21-23).

Basionym: Coscinodiscus eccentricus Ehrenberg (1840b), p. 146.

Remarks: This species was found rarely in the Antarctic as well as the subantarctic region and is cosmopolitan (Hustedt [1930], 1977).

Thalassiosira elliptipora (Donahue) Fenner ex Mahood et Barron (1996b), p. 292, pl. 4, fig. 3; pl. 5, figs. 4-7; pl. 8, figs. 6, 7; Harwood and Maruyama (1992), p. 707, pl. 16, fig. 12; Zielinski and Gersonde (2002), p. 263, pl. 5, fig. 1 (no illustrations).

Basionym: Coscinodiscus elliptipora Donahue (1970), p. 183, pl. 4, figs. e, i-m; McCollum (1975), p. 526, pl. 16, fig. 10; Gombos (1977), p. 592, pl. 3, figs. 1-3, 6; pl. 9, fig. 3; Ciesielski (1986), p. 875, pl. 1, fig. 6.

Remarks: Fenner (1991a) suggested that this endemic Southern Ocean species was most common in northern Antarctic surface waters.

Thalassiosira fasciculata Harwood et Maruyama (1992), p. 707, pl. 15, figs. 4-6; Mahood and Barron (1996a), pp. 287-291, figs. 15-24, 27, 28; Zielinski and Gersonde (2002), p. 263, pl. 5, figs. 3, 4 (Pl. P2, figs. 24, 25).

Thalassiosira gracilis (Karsten) Hustedt (1958), p. 109, figs. 1-7; McCollum (1975), p. 536, pl. 14, fig. 3; Fenner et al. (1976), p. 780, pl. 9, figs. 12-20; Iwai and Winter (2002), p. 12, pl. P12, fig. 4; pl. P24, fig. 2 (Pl. P2, figs. 26, 27).

Basionym: Coscinodiscus gracilis Karsten (1905), p. 78, pl. 3, fig. 4 .

Remarks: Fenner et al. (1976) indicated this species was found from the Antarctic waters and Antarctic Convergence Zone.

Thalassiosira gravida Cleve (1896), p. 12, pl. 2, figs. 14-16; Fenner et al. (1976), p. 780, pl. 8, fig. 5 (no illustrations).

Remarks: This species is reported from the polar and temperate North Atlantic (Hustedt [1930], 1977). 
Thalassiosira inura Gersonde (1991), p. 151, pl. 6, figs. 714; pl. 8, figs. 1-6; Baldauf and Barron (1991), p. 591, pl. 6, fig. 9; Harwood and Maruyama (1992), p. 707, pl. 5, fig. 14; pl. 14, figs. 12-16; Harwood et al. (2000), p. 460, fig. 7b; Censarek and Gersonde (2002), p. 353, pl. 4, figs. 11, 12; Iwai and Winter (2002), p. 12, pl. P12, figs. 2, 3; pl. P26, figs. 8, 9; pl. P27, fig. 3; Zielinski and Gersonde (2002), p. 264, pl. 5, figs. 12, 13 (no illustrations).

Thalassiosira lentiginosa (Janisch in Schmidt) Fryxell (1977), p. 103, figs. 13a-13d, 14a-14d; Harwood and Maruyama (1992), p. 707, pl. 19, fig. 15; Iwai and Winter (2002), p. 13, pl. P20, figs. 1, 4; pl. P24, fig. 4 (Pl. P2, figs. 28, 29).

Basionym: Coscinodiscus lentiginosus Janisch in Schmidt (1878), pl. 58, fig. 11; McCollum (1975), p. 527, pl. 5, fig. 1; Fenner et al. (1976), p. 773, pl. 7, figs. 4-6; Gombos (1977), p. 593, pl. 3, figs. 4, 5.

Remarks: This species is characteristic of the Antarctic region and is also widespread in subantarctic waters, although small numbers were found in the subtropical assemblage (Fenner et al., 1976).

Thalassiosira lineata Jousé (1968), p. 13, pl. 1, figs. 1, 2; Fenner et al. (1976), p. 780, pl. 11, figs. 8-10 (Pl. P2, figs. 30-33).

Remarks: This species is described as a tropical to subtropical species, but also occurs in colder waters (Fenner et al., 1976).

Thalassiosira oestrupii (Ostenfeld) Proschkina-Lavrenko ex Hasle (1960), p. 8, pl. 1, figs. 5, 7, 11; Fenner et al. (1976), p. 780, pl. 9, figs. 1-11; Gombos (1977), p. 598, pl. 5, figs. 1, 2; Gersonde and Burckle (1990), p. 782, pl. 3, figs. 13, 14; Harwood and Maruyama (1992), p. 708, pl. 16, figs. 5-7; Censarek and Gersonde (2002), p. 353, pl. 5, figs. 9, 10; Iwai and Winter (2002), p. 13, pl. P26, figs. 6a, 6b (Pl. P4, figs. 1-10).

Basionym: Coscinosira oestrupii Ostenfeld (1900), p. 52.

Remarks: This species is considered to be a subtropical indicator (Koizumi et al., 2004), but is cosmopolitan and reported from the subantarctic by several authors (e.g., Fenner et al., 1976).

Thalassiosira oliverana (O'Meara) Sournia; Harwood and Maruyama (1992), p. 708, pl. 14, figs. 1, 2, 6, 11, 17; Harwood et al. (2000), p. 460, fig. 7c (Pl. P4, figs. 31, 32).

Thalassiosira striata Harwood et Maruyama (1992), p. 708, pl. 15, figs. 7-9; Iwai and Winter (2002), p. 13, pl. P15, fig. 4; pl. P27, fig. 2; Zielinski and Gersonde (2002), p. 264, pl. 4, fig. 7 (Pl. P4, figs. 11, 12).

Thalassiosira sp. d of Fenner et al. (1976), p. 780, pl. 8, figs. 8, 9 (Pl. P4, figs. 13-26; Pl. P11, fig. 3).

Thalassiosira spp. (Pl. P4, figs. 27-30).

Thalassiothrix longissima Cleve et Grunow in Grunow (1880), p. 108; Schrader (1976), p. 637, pl. 1, figs. 5, 6, 17; Fenner et al. (1976), p. 781; Harwood and Maruyama (1992), p. 708, pl. 11, fig. 12 (Pl. P3, figs. 7578).
Remarks: This species is one of the most common plankton species of the ocean and is also found in the Antarctic and subantarctic regions (Fenner et al., 1976).

Triceratium spp. (Pl. P4, figs. 33, 34).

Tropidoneis spp. (Pl. P3, figs. 79, 80).

Genus et species indet. (Pl. P4, figs. 35-42).

\section{Littoral to neritic}

Actinoptychus senarius (Ehrenberg) Ehrenberg (1843), pp. 298, 301, 322, 328, 437, 438, 443, pl. I/I, fig. 27; pl. I/III, fig. 21; pl. III/VII, fig. 1; Censarek and Gersonde (2002), p. 350, pl. 5, fig. 11 (Pl. P5, figs. 1-10).

Basionym: Actinocyclus senarius Ehrenberg (1837), p. 61.

Remarks: This species is neritic to littoral (Koizumi et al., 2004) and cosmopolitan.

Cocconeis costata Gregory (1855), p. 39, pl. 4, fig. 10; Harwood et al. (2000), p. 459, fig. 9h; Iwai and Winter (2002), p. 4, pl. P6, fig. 16 (Pl. P6, figs. 1-4).

Cocconeis fasciolata (Ehrenberg) Brown (1920), p. 232; Harwood et al. (2000), p. 459, figs. 9c, 9d; Iwai and Winter (2002), p. 4, pl. P6, fig. 20 (Pl. P6, figs. 5-10).

Basionym: Rhaphoneis fasciolata Ehrenberg (1844a), p. 204.

Cocconeis aff. placentula Ehrenberg (1838), p. 194; Fenner et al. (1976), p. 771, pl. 11, fig. 13 (Pl. P6, figs. 11-20; Pl. P11, figs. 7, 8).

Cocconeis schuettii Van Heurck (1909), p. 18, pl. 2, fig. 29; Harwood et al. (2000), p. 459, figs. 9a, 9b, 9f (Pl. P6, figs. 21-29).

Cocconeis sp. A of Harwood et al. (2000), p. 459, figs. 9u, 9v (Pl. P6, figs. 30, 31).

Cocconeis sp. B (Pl. P6, figs. 32-39; Pl. P11, fig. 4).

Cocconeis spp. (Pl. P6, figs. 40-43).

Delphineis spp. (no illustrations).

Diploneis bombus Ehrenberg (1844b), p. 84; Censarek and Gersonde (2002), p. 351, pl. 5, fig. 3 (Pl. P7, figs. 1-6).

Diploneis frickei (Van Heurck) Heiden et Kolbe (1928), p. 613; Harwood et al. (2000), p. 459, fig. 9m (Pl. P7, figs. 7-12).

Basionym: Navicula frickei Van Heurck (1909), p. 10, pl. 2, fig. 184.

Diploneis splendida (Gregory) Cleve (1894), p. 87; Harwood et al. (2000), p. 459, fig. 9n (Pl. P7, figs. 13-18).

Basionym: Navicula splendida Gregory (1856), p. 44, pl. 5, fig. 14 .

Diploneis subovalis Cleve (1894), p. 96, pl. 1, fig. 27; Harwood et al. (2000), p. 459, fig. 91 (Pl. P7, figs. 19-24).

Diploneis sp. (lanceolate) (Pl. P7, figs. 25-28).

Diploneis spp. (P1. P7, figs. 29, 30). 
Grammatophora spp. (P1. P7, figs. 31-46).

Hyalodiscus spp. (Pl. P5, figs. 11-16).

Navicula directa (Smith) Ralfs in Pritchard (1861), p. 906; Fenner et al. (1976), p. 774, pl. 14, fig. 7 (Pl. P6, figs. 44, 45).

Basionym: Pinnularia directa Smith (1853), p. 56, pl. 18, fig. $172 \mathrm{~b}$.

Remarks: A cosmopolitan species, more common in colder waters (Fenner et al., 1976).

Navicula udintsevii Schrader et Fenner (1976), p. 991, pl. 22, fig. 33; pl. 24, figs. 1, 2; Gombos and Ciesielski (1983), p. 602, pl. 21, fig. 8; Harwood and Maruyama (1992), p. 704, pl. 2, fig. 12 (no illustrations).

Navicula wisei Harwood et Maruyama (1992), p. 704, pl. 17, figs. 9, 10 (Pl. P6, figs. 46, 47).

Navicula spp. (Pl. P6, figs. 48-51).

Nitzschia panduriformis Gregory (1857), p. 57, pl. 6, fig. 102 (Pl. P6, figs. 52-57; Pl. P11, figs. 5, 6).

Remarks: Littoral species (Koizumi et al., 2004).

Pleurosigma directum Grunow in Cleve et Grunow (1880), p. 53; Fenner et al. (1976), p. 778, pl. 14, fig. 6; Gombos and Ciesielski (1983), p. 603, pl. 24, fig. 9 (Pl. P8, figs. 1, 2).

Remarks: Cosmopolitan species (Hasle and Syvertsen, 1996).

Paralia sulcata (Ehrenberg) Cleve (1873), p. 7; Iwai and Winter (2002), pl. P8, fig. 7; pl. P25, fig. 17; pl. P29, fig. 9; pl. P32, fig. 2; Arney et al. (2003), p. 9, pl. P1, fig. 5 (Pl. P5, figs. 17-23).

Basionym: Gaillonella sulcata Ehrenberg (1838), p. 170, pl. 21, fig. 5.

Synonym: Melosira sulcata (Ehrenberg) Kützing (1844), p. 55 , pl. 2, fig. 7 .

Remarks: This species is a bottom form but is fairly common in coastal plankton, cosmopolitan (Hasle and Syvertsen, 1996).

Rhaphoneis amphiceros (Ehrenberg) Ehrenberg (1844b), p. 87; Ciesielski (1986), p. 877, pl. 6, figs. 1-3 (Pl. P6, figs. 58-63). 206.

Basionym: Cocconeis amphiceros Ehrenberg (1840a), p.

Remarks: Probably cosmopolitan (Hasle and Syvertsen, 1996).

Rhaphoneis spp. (Pl. P8, figs. 3-8).

Rhopalodia spp. (Pl. P8, figs. 9, 10).

Stauroneis spp. (Pl. P8, figs. 11-16).

Surirella spp. (no illustrations).

Trachyneis spp. (Pl. P8, figs. 17-20).

Stephanopyxis spp. (Pl. P8, figs. 21-34).

Remarks: Several shapes of valves, for example flat and strongly vaulted ones with/without conical processes, were recognized, but firm classification of this genus has not been estimated so far.
Thalassionema nitzschioides (Grunow) Mereschkowsky (1902), p. 78 (Pl. P8, figs. 35-48).

Basionym: Synedra nitzschioides Grunow (1862), p. 403, pl. 5/8, fig. 18 .

Synonym: Thalassionema nitzschioides (Grunow) Van Heurck (1896), p. 319, fig. 75; Ciesielski (1986), p. 877, pl. 3, fig. 17; Iwai and Winter (2002), p. 11, pl. P5, fig. 18.

Remarks: Cosmopolitan but not in the high Arctic and Antarctic (Hasle and Syvertsen, 1996).

\section{Fresh or brackish water}

Aulacoseira granulata (Ehrenberg) Simonsen (1979), p. 58 (Pl. P9, figs. 1-8).

Basionym: Gaillonella granulata Ehrenberg (1843), p. 415.

Synonym: Melosira granulata (Ehrenberg) Ralfs in Pritchard (1861), p. 820.

Cyclotella pantanelliana Castracane (1886b), p. 171 (Pl. P9, figs. 9-18).

Cyclotella spp. (no illustrations).

Cymbella spp. (Pl. P9, figs. 19-30).

Discostella stelligera (Cleve et Grunow) Houk et Klee (2004), p. 208 (Pl. P9, figs. 31-44).

Basionym: Cyclotella meneghiniana var. stelligera Cleve et Grunow in Cleve (1881), p. 22, pl. 5, figs. 63a, 63c.

Synonym: Cyclotella stelligera (Cleve et Grunow in Cleve) Van Heurck (1882), pl. 94, figs. 22-26.

Remarks: The type specimen was collected from the Lake Rotoaira, south of the Lake Taupo, New Zealand (Houk and Klee, 2004).

Encyonema spp. (P1. P9, figs. 45-48).

Epithemia spp. (P1. P9, figs. 49-52).

Eunotia spp. (Pl. P9, figs. 53-56).

\section{Coastal upwelling indicator, resting spores of Chaetoceros}

Coronodiscus collarius Suto (2004a), p. 96, figs. 2A, 5-35 (Pl. P10, figs. 1, 2; P1. P12, fig. 1).

Dicladia capreola Ehrenberg (1854), pl. 35A, fig. 8; Suto (2003), pp. 337-339, figs. 1B, 17-30, 124, 125 (Pl. P10, figs. 3-6).

Remarks: The vegetative diatom, Chaetoceros lorenzianus Grunow, is a widely distributed neritic, tropical, and temperate species (Lee, 1993).

Dicladia ? spp. (P1. P10, figs. 7-10).

Dispinodiscus pilusus var. montanus Suto (2004b), pp. 87-89, figs. 1M-1R, 45-56 (Pl. P10, figs. 11-16; Pl. P12, fig. 2).

Dispinodiscus pilusus var. pilusus Suto (2004b), pp. 81-87, figs. 1A-1I, 57-88 (Pl. P10, figs. 17, 18).

Dispinodiscus stimulus Suto (2004b), pp. 80-81, figs. 1J-1L, 6-31, 43, 44 (Pl. P10, figs. 19-24). 
Gemellodiscus bifurcus Suto (2004c), p. 269, figs. 2.F, 2.G, 10.1-10.25 (Pl. P10, figs. 25-34; Pl. P12, fig. 3).

Gemellodiscus cingulus Suto (2004c), p. 267, figs. 2.C, 2.D, 8.1-8.10, 8.15 (Pl. P10, figs. 35, 36).

Hypovalve of Gemellodiscus (see Suto, 2004d) (Pl. P10, figs. $37,38)$.

Liradiscus castaneus var. castaneus Suto (2007), p. 146, pl. 2, figs. 1a-3c, 7a, 7b, 14a, 14b (Pl. P10, figs. 39-46; Pl. P12, fig. 4).

Remarks: The last occurrence age of this species recognized from IODP Expedition 317 Hole U1352B coincides with that from DSDP Site 436, northwestern Pacific in the middle Pleistocene (Suto, 2007); therefore, this species may be potentially useful for Pacific diatom biostratigraphy because of its specific characteristic allowing for easy identification.

Liradiscus japonicus Suto (2004e), pp. 69-70, pl. 3, figs. 1a10 (Pl. P10, figs. 47, 48).

Liradiscus pacificus Suto (2004e), pp. 69-70, pl. 3, figs. 1a10 (Pl. P10, figs. 49, 50).

Liradiscus plicatulus Hajós (1968), p. 114, pl. 28, fig. 10; Suto (2004e), pp. 69-70, pl. 3, figs. 1a-10 (Pl. P10, figs. 51-54; Pl. P12, fig. 5).

Monocladia sp. (Pl. P10, figs. 55, 56).

Remarks: About this genus, see Suto (2003, 2005a).

Quadrocistella rectagonuma Suto (2006a), p. 17, pl. 5, figs. 113 (Pl. P10, figs. 57-62; Pl. P12, fig. 6).
Syndendrium diadema Ehrenberg (1854), pl. 35A, group 18, fig. 13; Suto (2003), pp. 342-349 (Pl. P10, figs. 63-74).

Remarks: The extant Chaetoceros diadema considered as the vegetative diatom of this resting spore species is cosmopolitan (Hasle and Syvertsen, 1996).

Truncatulus spp. (no illustrations).

Remarks: About this genus, see Suto (2006c).

Vallodiscus complexus Suto (2005b), p. 22, figs. 2D-2F, 3368 (Pl. P10, figs. 75-78).

Xanthiopyxis hirsuta Hanna et Grant (1926), p. 170, pl. 21, fig. 10; Suto (2004d), pp. 297-299, figs. 1.I1, 1.I2, 11.25-11.28, 13.8 (Pl. P10, figs. 79-84).

Xanthiopyxis polaris Gran (1900), p. 51, pl. 3, figs. 16-19; Suto (2004d), figs. 1.A, 7.1-7.17 (Pl. P10, figs. 85, 86).

Xanthiopyxis type A (knobby type) of Suto (2004d), p. 303, figs. 1.L1, 1.L2, 7.32-7.35, 10.1-10.28 (Pl. P9, figs. 5762; P1. P12, fig. 7).

Xanthiopyxis type B (short spiny type) of Suto (2004d), pp. 303-307, figs. 1.M1, 1.M2, 12.1-12.32, 13.1-13.7 (Pl. P9, figs. 63-78; P1. P12, fig. 8).

Xanthiopyxis type C (long spiny type) of Suto (2004d), p. 307, figs. 1.N, 12.33-12.40 (Pl. P9, figs. 79-84).

Hyaline type resting spores (P1. P9, figs. 85-96).

Remarks: This hyaline type resting spores have no characteristics on its epivalve surface, but its hypovalve possesses a ring of puncta at the mantle margin. 